\title{
THE TEMPORAL RELATIONS OF MEANING AND IMAGERY
}

\author{
BY THOMAS VERNER MOORE \\ Catholic University of America

\section{The Problem}

The experiments here reported constitute a part of a more extensive study of memory and perception, which will probably be made public in the future. The work was done in the laboratory of Professor Külpe at Munich. The part now published cannot, however, be properly evaluated without some indication of the nature of the results obtained in the first section of the more extensive study. This first part consisted in an introspective investigation of the mental processes involved in perception and recall.

The material for experiment in the unpublished section consisted of spoken words, printed words, printed pictures and real objects. A series of eight words, pictures or objects were presented to the subjects. Their task was to repeat what they had seen or heard and then to give an introspective account of the mental processes they had experienced during the perception of the series and during their attempts to reproduce the same from memory. ${ }^{1}$ The subjects were asked particularly to give an account of the temporal sequence of events as they had experienced them.

It was rather remarkable that in perceiving, the first thing in consciousness was reported as meaning the second some kind of imagery. Whereas in repeating the first thing was often an image whose meaning was understood and then designated by a word.

A few introspections will bring out more clearly what is meant by this assertion.

${ }^{1}$ A fuller description of the details of the.technique will be given when the entire work is made public. 


\section{Perception of Printed Words}

"I notice now a certain regularity in this process. With the first word, the meaning appeared with the reading, without any clear visual image of the object thereby designated. The same process takes place on the continuation of the series of words. Gradually it goes on so rapidly that during the period of exposition ( 2 seconds) there is time to apprehend a goodly number of apperceptive complexes, which become associated with the imaged object. The steps in the process - so far as I can notice them-are:

"I. Apprehension of the meaning.

"2. Imagery of the object-generally by means of memory images.

"3. Associations which are connected with the object." Subject Lehner, Nov. 17. ${ }^{1}$

\section{Perception of Pictures}

"I look at the picture and generally have its meaning at once. Often I am not entirely certain, e. g., spoon or trowel. When I have the meaning, its naming follows immediately." -Grüninger, Dec. $17 .^{2}$

"In the perception of the several pictures, I notice that I experienced auditory-motor words in immediate connection with them, and that these words followed with varying rapidity the individual pictures. It lasted some time till I got the word 'Mitre.' In this experience it appeared to me that the rapidity with which the word comes, does not depend as much upon the finding of the words as it does upon the

${ }^{1}$ Ich merke jetzt eine gewisse Gesetzmässigkeit des Prozesses. Bei dem ersten Wort tritt mit dem Lesen die Bedeutung bewusst auf, ohne deutliches Gesichtsbild des darin fixierten Objektes. Derselbe Vorgang vollzieht sich bei der Fortsetzung der Reihe, allmàhlich mit so grosser Schnelligkeit dass während der Exponierungszeit noch Zejt bleibt eine ganze Fülle von Apperceptionsmassen bewusst zu erfassen, die sich an das vorgestellte Objekt noch knupfen. Die Stufen so weit ich sie bemerken kann sind: 1. Erfassung der Bedeutung. 2. Vorstellung des Objektes, gewöhnlich durch Erinnerungsbilder. 3. Associationen die sich an das Objekt knüpfen. (I7ten. Nov.)

2 Ich sehe das Bild and und meistens habe ich sofort die Bedeutung. Manchmal bin ich nicht ganz sicher z. B. Löffel oder Kelle. Wenn ich die Bedeutung habe, folgt sofort die Benennung. 
recognition of the picture. It is on this account that I would willingly have looked longer at the pictures. The words served as designations for the pictures or if you will the objects represented by the pictures, and had another sense, a more general meaning than their relation to the individual pictures or their objects."-Subject Külpe, Nov. 14. ${ }^{1}$

\section{Repetition of OBjects}

"On repeating, there comes to me all of a sudden a visual image. When this image comes promptly it is usually complete. But when I must think awhile, there comes to me first of all something striking in the object. Then come further qualities, e.g., to the color the form. As soon as this process of supplementing has developed to a certain point, the meaning is all of a sudden present. As soon as I have the meaning, the object seems to become still clearer. $E$. g.: All of a sudden I see the typical lustre of a pearl. Then there comes to me the round form and then all at once I know what it is."-Subject Grüninger, Dec. 10."

Were meaning in some manner identical with imagery, or were it produced by imagery or the imaginal context of a sensation as Titchener suggests is often the case, we should expect just such introspections as this from our subjectsnot however for memory but for perception. That they are

${ }^{I}$ Ich bemerke dass ich bei der Wahrnehmung der einzelnen Bilder sofort akustischmotorische Wörter in Anschluss an sie erlebt habe, und dass diese Wörter in verschiedener Geschwindigkeit sich an die einzelnen Bilder anschlossen. Bei dem Wort Bischofsmütze, z. B., dauerte es ziemlich lang bis ich es fang. Dabei schien die Gescbwindigkeit des Auftretens der Wörter nicht sowohl in der Wortfindung selbst als vielmehr in der Erkennung des Bildes begründet zu sein. Damit hängt es zusammen dass ich einige Bilder gerne länger betrachtet hätte. Die Wörter galten als die Bezeichnungen für die Bilder bzw. die Gegenstande die in ihnen dargestellt waren, und hatten einen anderen Sinn, eine allgemeinerc Bedeutung als die Beziehung auf die einzelnen Bilder oder ihre Gegenstande. (14ten Nov.)

2 Beim Herbagen taucht einfach ganz plotzlich ein optisches Bild auf. Wenn das Bild schnell auftritt, dann ist es meistens vollständig. Wenn ich einige Zeit suchen muss, dann taucht zuerst etwas besonders auffalliges am Gegenstand auf. Dann kommen weitere Qualitāten, z. B. zur Farbe die Form, und sobald diese Ergänzung einen grösseren Grad erreicht hat ist die Bedeutung auf einmal da, und sobald ich die Bedeutung habe, scheint mir der Gegenstand noch deutlicher zu werden. Z. B. Ich sehe auf einmal den eigenartigen Glanz der "Perle." Dann kommt mir die runde Form, und dann auf einmal weiss ich was es ist. (roten Dez.) 
found in memory and not in perception is strong evidence against any such theory. Here the nature of the occurrence points to the fact that an image as such means nothing just as Professor Titchener himself claims. It must be interpreted. It can be interpreted only when sufficient data is present. When this is the case, the subject knows what it is. This knowledge of what the image represents is not reported as a sensory element added to the elaboration of the image. A new image would itself have to be recognized. The interpretation of the image is a knowing. It is something which follows the awareness of the image just as understanding follows the sensations involved in perception.

\section{Repetition of Pictures}

"The repetition took place in this manner: First I thought of the first member of the series. Then without holding more strictly to the order of perception each word was spoken following an imaginal representation of the pictures. When I stopped, I attempted to bring up to myself the series. Only by the rising up of a visual image did I obtain a new word." -Subject Külpe, Nov. I4. ${ }^{1}$

Such introspections as these suggested a further investigation. The subjects had noticed a certain sequence of events in the process of perception. Would it be possible to react to the events that had been noted? If meaning comes before imagery in the perception of printed words, would it be possible for the subject to react, now to imagery and now to meaning? And if so, what would be the quantitative results?

In the experiments here reported this problem was attempted, to investigate, namely, by means of reaction time the temporal relations of meaning and imagery in the perception of printed words and pictures. The experiments were made in the psychological laboratory of Professor

1 Das Hersagen geshah so dass ich mich zunächst auf das erste Glied der Reihe zurückbesann. Danach wurden die einzelnen Wörter im Anschluss an die anschaulichen Vorstellungen der Bilder ohne die Ordnung der Wahrnehmung strenger einzuhalten ganannt. Wenn ich stockte, suchte ich mir die Reihe wiederzuvergegenwärtigen und bekam erst durch eine neue Auftauchung des Vorstellungsbildes ein neues Wort (Nov. $r_{4}$ th). 
Külpe in Munich during the winter semester of 1913-14 and the summer semester of 1914. The author wishes to take this opportunity to thank Professor Külpe for his great kindness, for his interest and suggestions, and for the sacrifice of his time as subject.

\section{Method of Research}

The words and pictures used in these experiments designated simple familiar objects-all capable of being visualized; e. g., tree, lamp, knife. Abstract words, prepositions, etc., were not used, in order that conditions might be as favorable as possible for the development of imagery. Had such words been used the difference that was found in reaction time for meaning and imagery would have been much greater. The use of such words would indeed have been justified. For if sensations and images must explain all meanings they must be involved, and exclusively involved, not merely in the perception of things that can be immediately sensed, but also in more abstract mental content. In order, however, to test the theory on the ground where it is best able to stand, it was concluded to forego the use of any words except those that represented familiar sensory objects.

The accompanying plates give an insight into the material used in these experiments. Most of them represent objects that can be named by a one or two syllable German word. The words used were printed on cards in a large legible type.

The use of control words and drawings enabled one to be sure that the subjects were actually reacting to meanings. The controls used in the series of words were nonsense combinations of letters forming one or two syllables. The controls used in the series of pictures were meaningless drawings. In general, the subject was instructed to react (by releasing a telegraph key) in case the word or the drawing represented some real object. The words were exposed by a combination memory and tachistoscope apparatus. The reaction times were measured by a Hipp chronoscope. This was controlled by a pendulum constructed in accordance with a design by Professor Külpe. The variable error in the 

182
T. V. MOORE
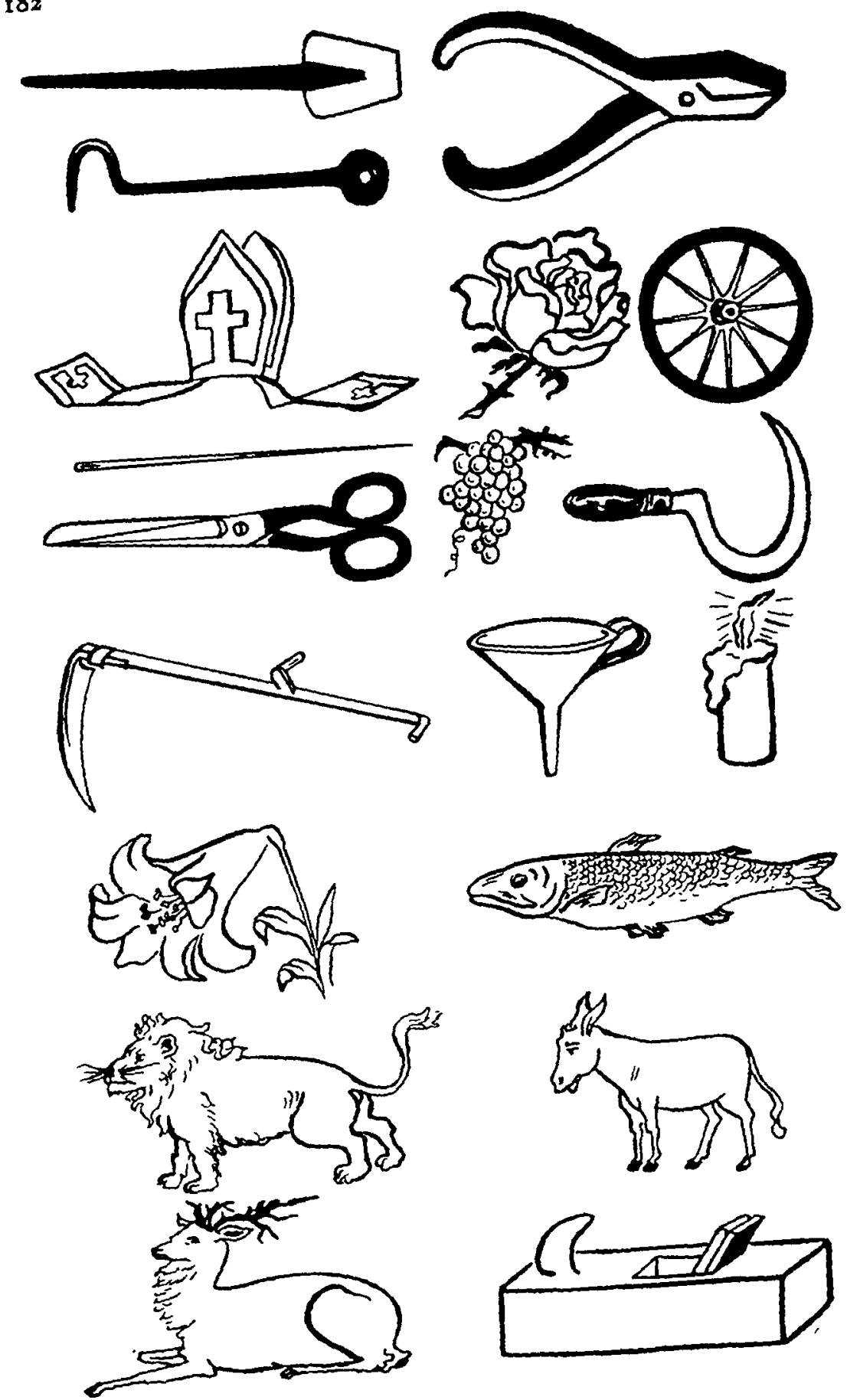

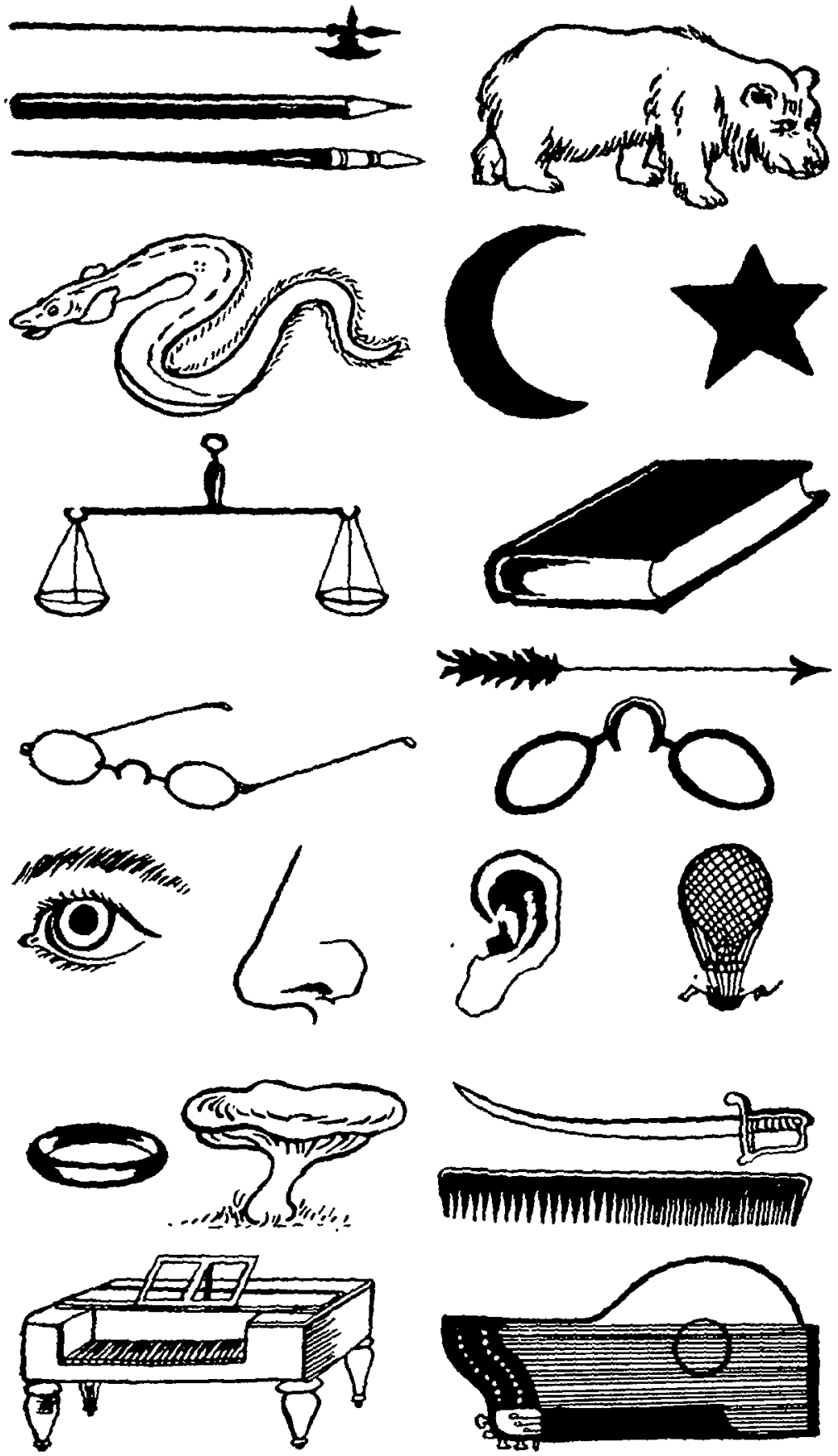

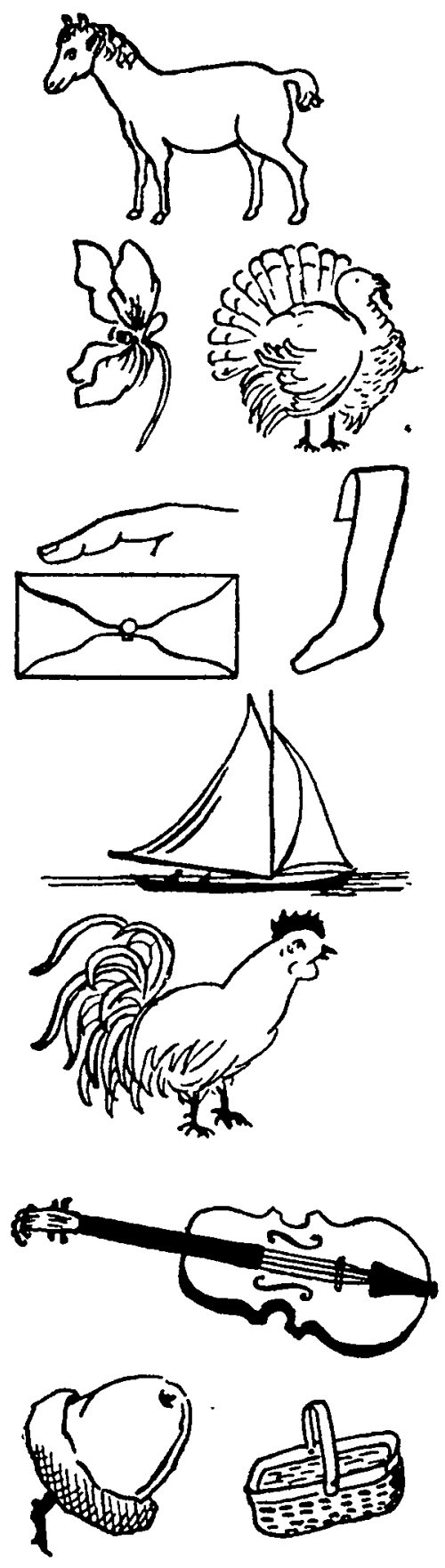
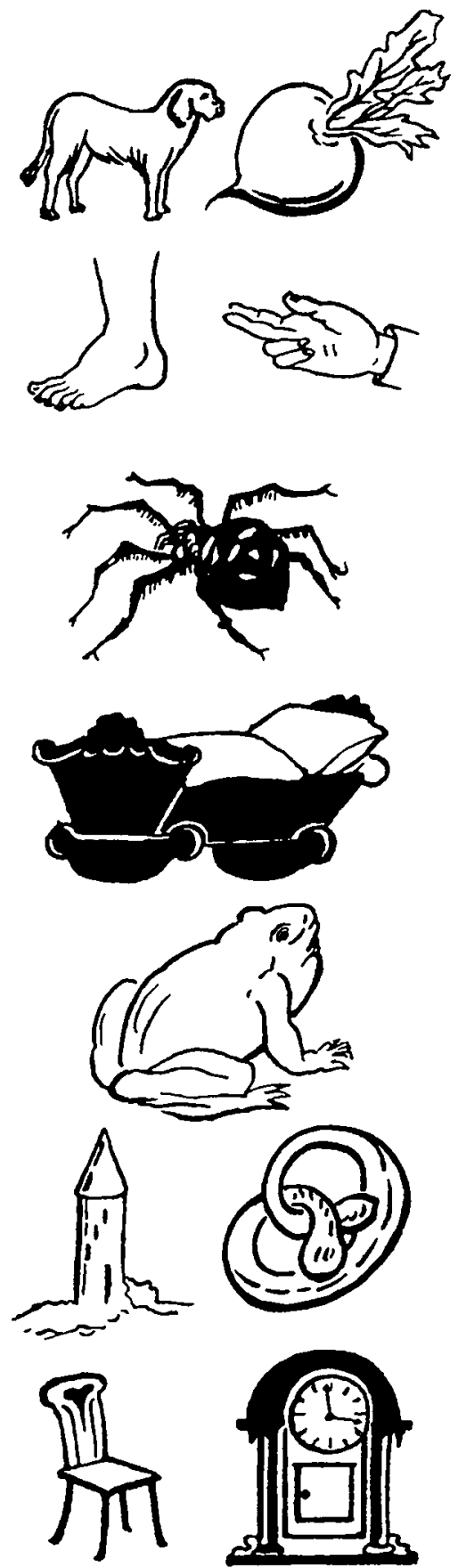


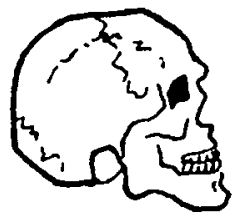
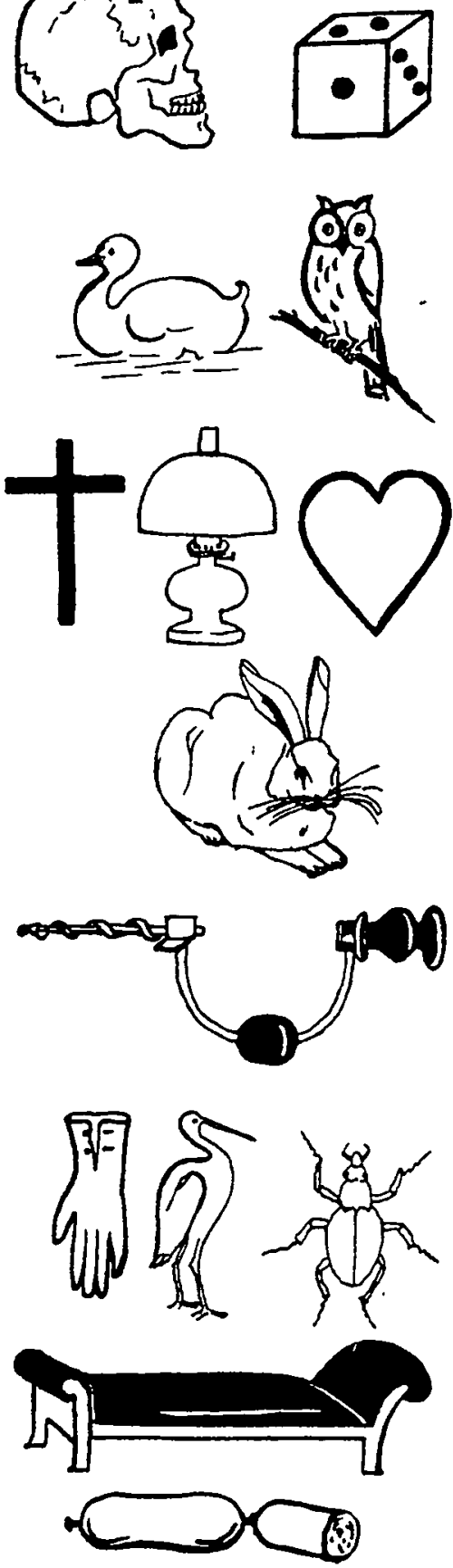
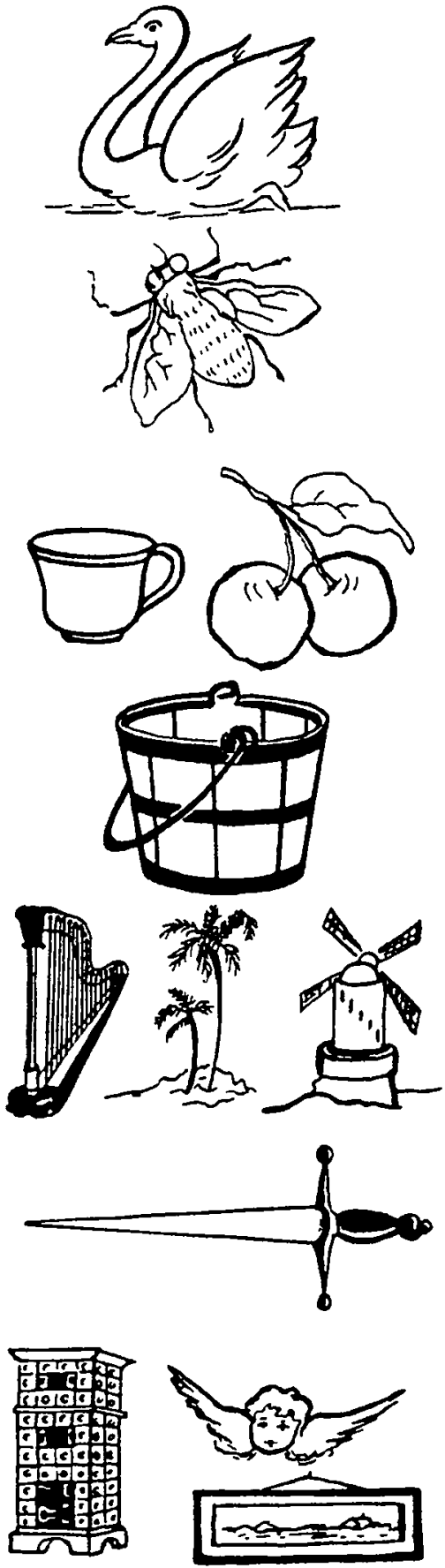

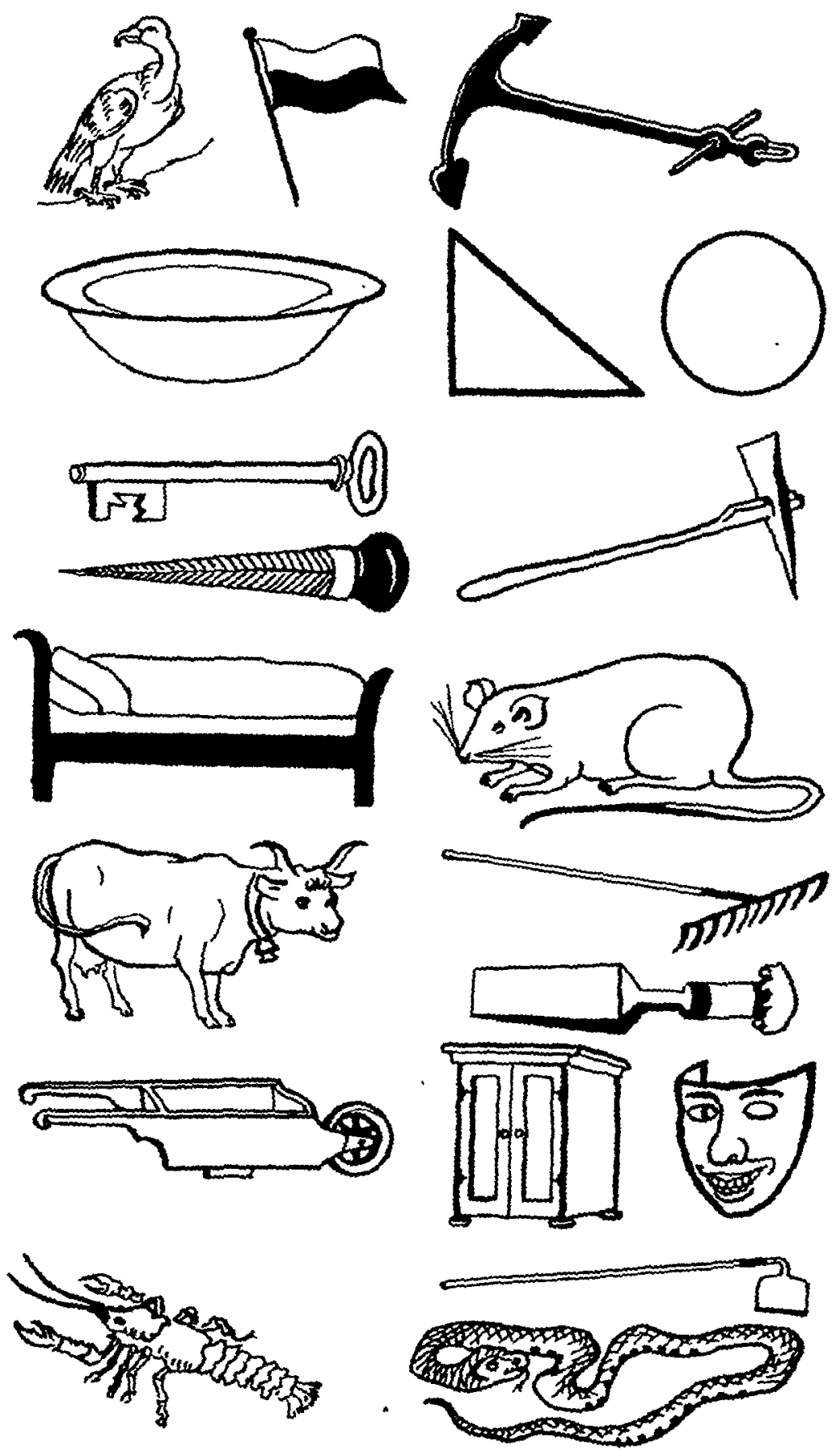

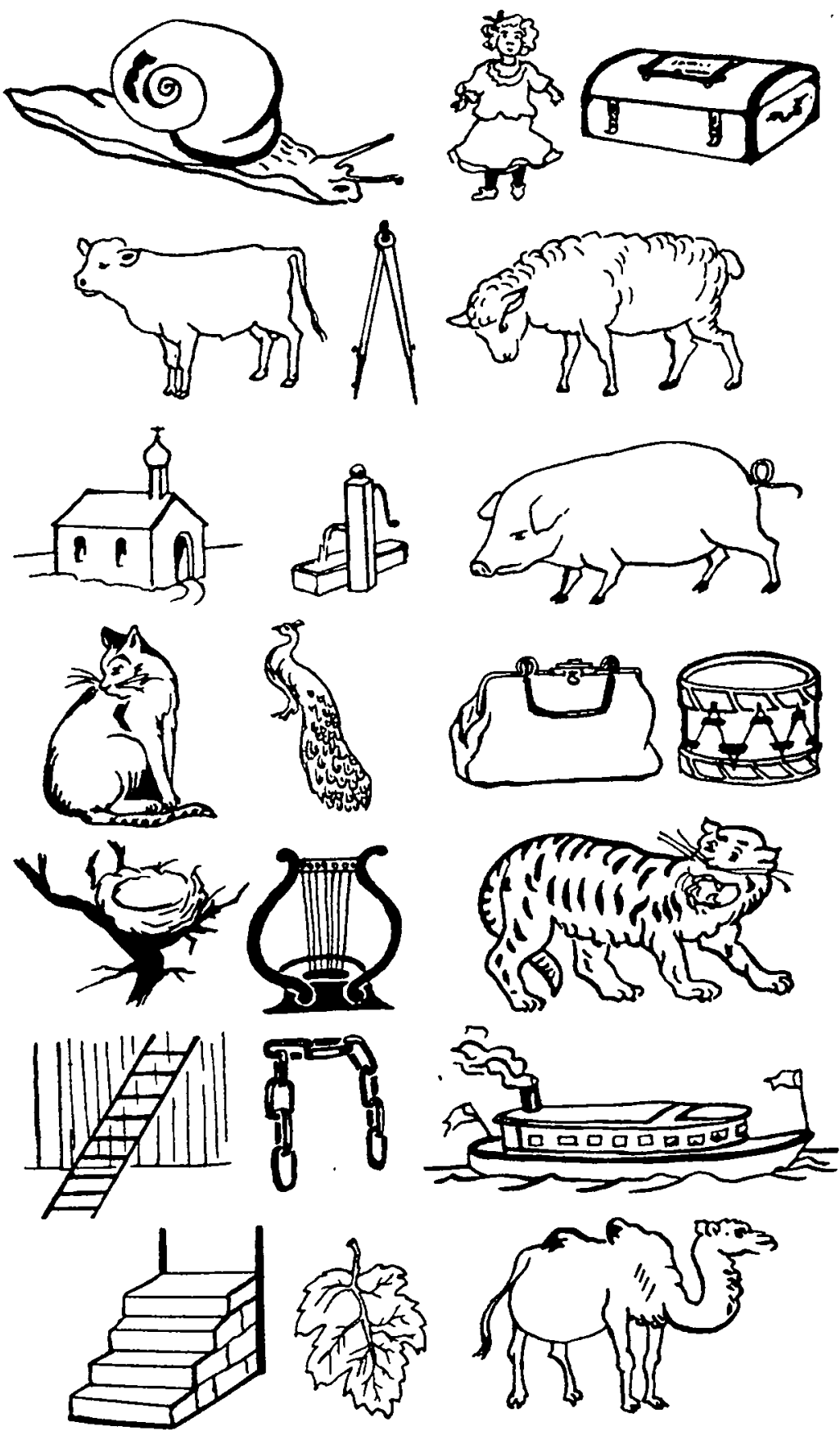


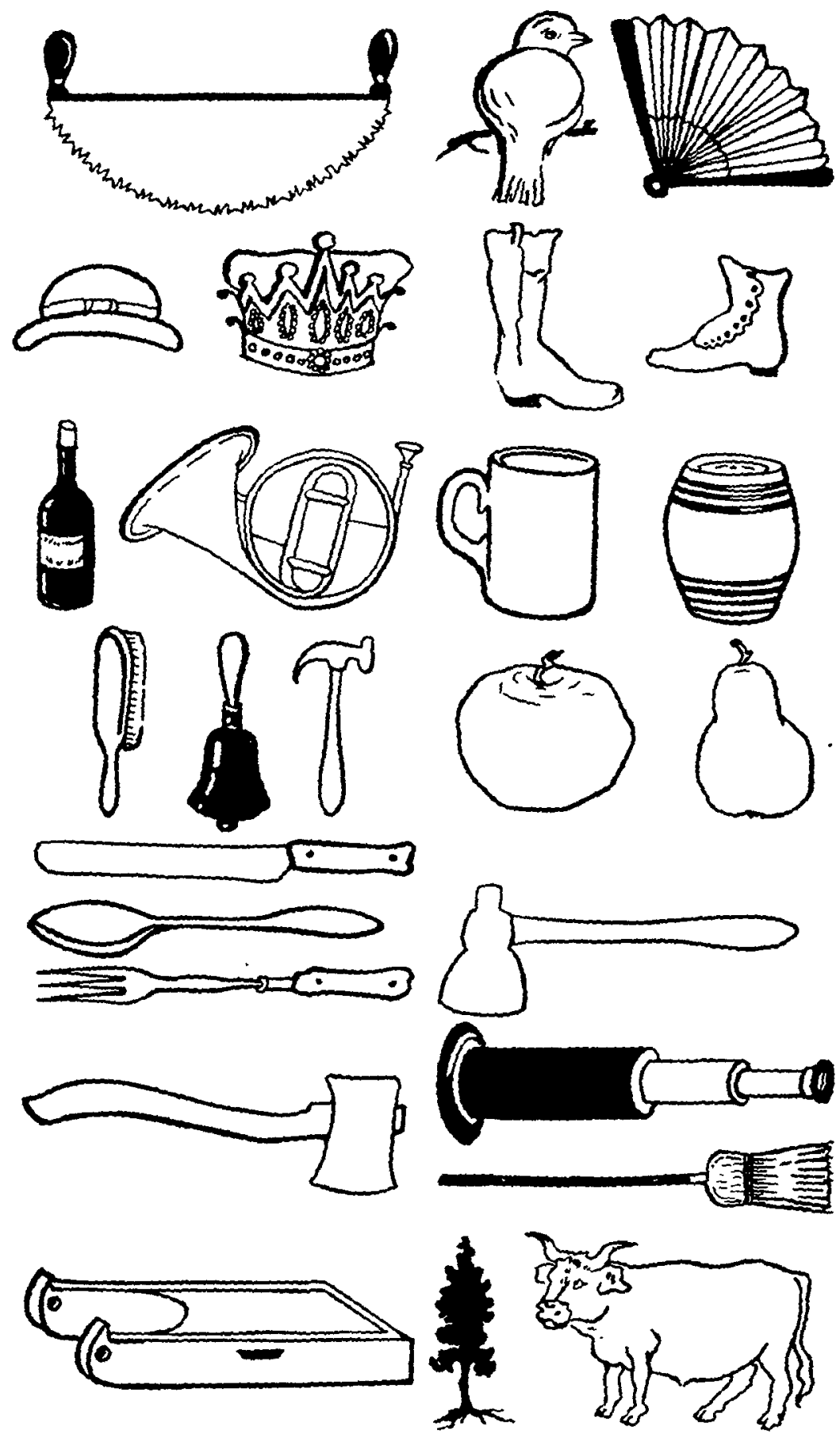


chronoscope was negligible-averaging less than $3 \sigma$. The constant error was about $70 \sigma$. Nine subjects took part in the experiments. A preparatory signal ( $\mathrm{I}-1 / 2 \mathrm{sec}$.) was given verbally with the aid of a stop watch.

\section{Simple ${ }^{1}$ Meaning and Visual Imagery}

\section{(a) Quantitative Results}

The instructions to the subject in this experiment will indicate the precise nature of the problem. They are reproduced without translation. The subject read them over at the beginning of each period. A few trial periods were necessary for some subjects in order that they might learn not to react to the control word. These preparatory series were not included in the final results. One of our subjects (Gl.) never did get free from erroneous reactions and his results show a marked difference from the others.

Sie werden nach einem Signal ein Wort zu sehen (bzw.zu hören) bekommen. Ich bitte Sie zu reagieren wenn Sie das Wort verstanden oder seine Bedeutung erfasst, bzw. wenn Sie eine Gesichtsvorstellung von dem durch das Wort bezeichneten Gegenstand gehabt haben.

Die Wörte 'Bedeutung' und 'Vorstellung' werden Ihnen angeben ob das eine oder das andere verlangt wird. Nachher bitte ich mir kurz das Erlebnis zu charakterisieren, and dabei anzugeben, ob die aufgetauchte Vorstellung an die Stelle der Bedeutung gesetzt werden konnte, etwa bloss die konkrete anschauliche Erfüllung dessen war, was in der Bedeutung abstrakt intendiert wurde.

In this series, therefore, the subject reacted either (a) To the awareness that the word had a meaning, or (b) To the awareness of the visual image of the object.

If there is no difference between meaning and the visual image of an object represented by a word the average of the two series should be approximately the same. The subject ought not to be able to distinguish meaning and imagery

I By 'simple meaning' is not meant an absolute simplicity. The word is used to contrast this set of experiments with a later one where the more complex consciousness of purpose was required. 
and this should manifest itself in averages for the two sets of reactions that approached each other within the limits of experimental error. If meaning, however, is produced by or is identical with the visual image which accrues to the sensations involved in the perception of the word, the image series should be shorter if anything than the meaning series. The results are given below. The tables are clear without any explanation, except perhaps, that in column $T$ is given the

Surject GI

Words

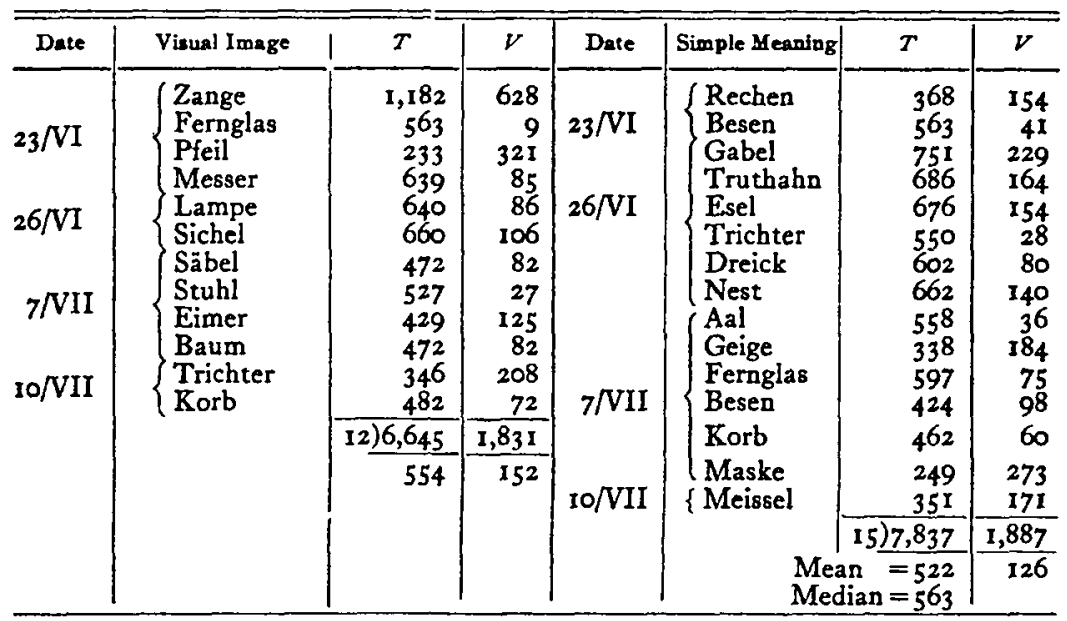

Reactions to visual imagery equal or below median $=8$.

Subject Grüninger

Words

\begin{tabular}{|c|c|c|c|c|c|c|c|}
\hline Date & Visual Image & $T$ & $V$ & Date & Simple Meaning & $T$ & $V$ \\
\hline \multirow[t]{2}{*}{$I I / I I$} & \multirow{8}{*}{$\begin{array}{l}\text { Auge } \\
\text { Ballon } \\
\text { Kuh } \\
\text { Bohrer } \\
\text { Sofa } \\
\text { Stiefel } \\
\text { Schuh } \\
\text { Fass } \\
\text { Nase }\end{array}$} & $\begin{array}{r}902 \\
1,092\end{array}$ & $\begin{array}{l}341 \\
151\end{array}$ & \multirow{8}{*}{$\begin{array}{l}I I / I I \\
I 6 / I I\end{array}$} & \multirow{7}{*}{$\begin{array}{l}\text { Schub } \\
\text { Nase } \\
\text { Fass } \\
\text { Schwan } \\
\text { Schaf } \\
\text { Ring } \\
\text { Auge } \\
\text { Ballon } \\
\text { Fass } \\
\text { Kub }\end{array}$} & $\begin{array}{l}682 \\
787\end{array}$ & $\begin{array}{l}18 \\
87\end{array}$ \\
\hline & & 1,660 & 417 & & & $66 \mathrm{I}$ & 39 \\
\hline $16 / 11$ & & $\begin{array}{l}1,277 \\
I, 261\end{array}$ & $\begin{array}{l}34 \\
18\end{array}$ & & & $\begin{array}{r}659 \\
781\end{array}$ & $8 I$ \\
\hline \multirow{5}{*}{$25 / 1 I$} & & 1,229 & 14 & & & $53 \mathrm{I}$ & 169 \\
\hline & & 1,103 & 140 & & & 680 & 20 \\
\hline & & $\begin{array}{l}1,462 \\
1,200\end{array}$ & $\begin{array}{r}219 \\
43\end{array}$ & & & $\begin{array}{l}705 \\
660\end{array}$ & $\begin{array}{r}5 \\
40 \\
\end{array}$ \\
\hline & & 9) 11,186 & 1,377 & & & 10) 7,002 & $\frac{6}{656}$ \\
\hline & & 1,243 & 153 & & \multicolumn{2}{|c|}{$\begin{array}{l}\text { Mean }=700 \\
\text { Median }=681\end{array}$} & 65 \\
\hline
\end{tabular}

Reactions to visual imagery equal to or below median $=0$. 
SUbJect KüLPE

Words

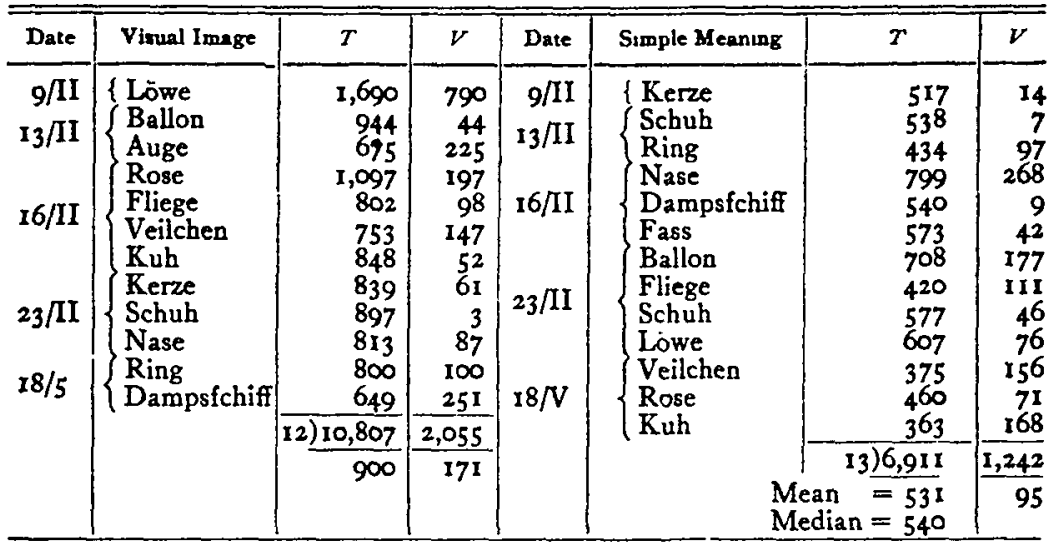

Reaction to visual imagery equal to or below median $=0$.

Subject Legner

Words

\begin{tabular}{|c|c|c|c|c|c|c|c|}
\hline Date & Visual Image & $T$ & $V$ & Date & Sumple Meaaing & $T$ & $V$ \\
\hline \multirow{7}{*}{ I6/II } & Rechen & $38 r$ & 263 & \multirow{8}{*}{$16 / \mathrm{II}$} & Schwan & 445 & 24 \\
\hline & Buch & $\mathrm{x}, \mathrm{I} 3 \mathrm{I}$ & 487 & & Bohrer & $x, \infty 7$ & 538 \\
\hline & Rettich & $6 \mathrm{II}$ & 33 & & Sofa & 663 & 194 \\
\hline & Nase & 604 & 40 & & Rose & 317 & 152 \\
\hline & Trichter & $5^{84}$ & 60 & & Brief & 691 & \\
\hline & Dreieck & 490 & 154 & & Palme & 500 & 31 \\
\hline & Blatt & 597 & 47 & & Baum & 399 & 70 \\
\hline \multirow[t]{5}{*}{ 30/VI } & $\begin{array}{l}\text { Bär } \\
\text { Krone }\end{array}$ & 606 & $\begin{array}{r}38 \\
165\end{array}$ & & $\begin{array}{l}\text { Hirsch } \\
\text { Spaten }\end{array}$ & $\begin{array}{l}389 \\
406\end{array}$ & $\begin{array}{l}80 \\
63\end{array}$ \\
\hline & Veilchen & $\begin{array}{l}479 \\
488\end{array}$ & 156 & \multirow[t]{5}{*}{$30 / \mathrm{VI}$} & Aal & 407 & 62 \\
\hline & Treppe & 631 & 13 & & Krug & 395 & 74 \\
\hline & Ofen & 572 & 72 & & Tasse & 489 & 20 \\
\hline & Säbel & 588 & $\begin{array}{r}56 \\
183\end{array}$ & & $\begin{array}{l}\text { Schädel } \\
\text { Ohr }\end{array}$ & $\begin{array}{l}426 \\
435\end{array}$ & 43 \\
\hline \multirow{5}{*}{$3 / \mathrm{VII}$} & Pfeil & 451 & 193 & & Spaten & $\begin{array}{l}518 \\
518\end{array}$ & 49 \\
\hline & Meissel & 515 & 129 & \multirow{4}{*}{$3 / \mathrm{VII}$} & Hirsch & $37 \mathrm{I}$ & 98 \\
\hline & Fernglas & 874 & 230 & & Baum & $4^{83}$ & 14 \\
\hline & Flasche & $75^{8}$ & $\mathrm{II}_{4}$ & & Palme & 524 & 55 \\
\hline & Krug & 691 & 47 & & Bär & 368 & 101 \\
\hline \multirow{5}{*}{$7 / \mathrm{VII}$} & Tasse & $\begin{array}{l}736 \\
738\end{array}$ & 92 & \multirow{2}{*}{$7 / \mathrm{VII}$} & Krone & 384 & 85 \\
\hline & $\begin{array}{l}\text { Schadel } \\
\text { Ohr }\end{array}$ & $\begin{array}{l}918 \\
844\end{array}$ & $\begin{array}{l}274 \\
200\end{array}$ & & $\begin{array}{l}\text { Uren } \\
\text { Veilchen }\end{array}$ & $\begin{array}{l}429 \\
344\end{array}$ & 125 \\
\hline & Ballon & 803 & I59 & & Treppe & 398 & 71 \\
\hline & & 23)14,813 & 3,205 & & & 23) 10,788 & 2,245 \\
\hline & & 644 & 139 & & & $\begin{aligned} \operatorname{ean} & =469 \\
\text { edian } & =429\end{aligned}$ & 97 \\
\hline
\end{tabular}

Reaction to visual imagery equal or below median $=\mathbf{r}$. 
Subject Marezoll

Words

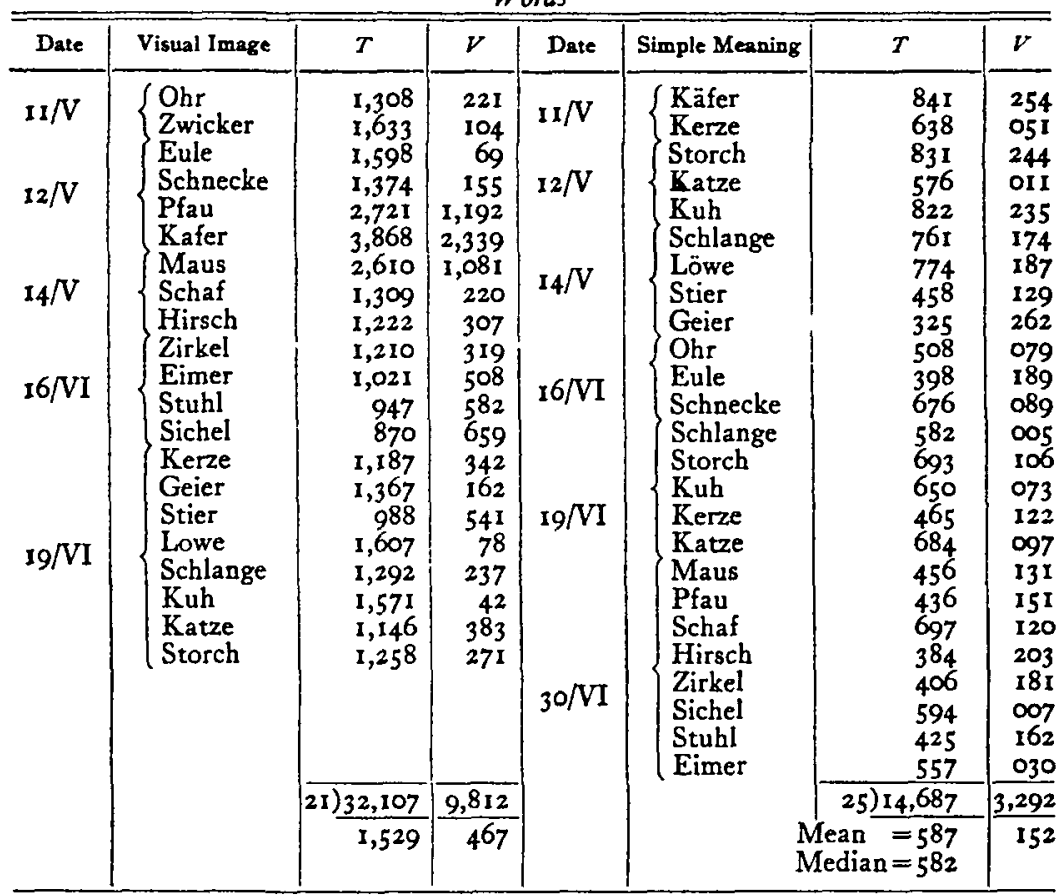

Reactions to visual imagery equal or below median $=0$.

Subject Moore

\begin{tabular}{|c|c|c|c|c|c|c|c|}
\hline Date & Visual Meaning & $T$ & $V$ & Date & Simple Meaning & $T$ & $v$ \\
\hline \multirow{6}{*}{$9 / \mathrm{NI}$} & Schuh & & 330 & \multirow{7}{*}{$9 / \mathrm{VI}$} & \multirow{15}{*}{$\begin{array}{l}\text { Finger } \\
\text { Buch } \\
\text { Schere } \\
\text { Bürste } \\
\text { Fernglas } \\
\text { Uhr } \\
\text { Schuh } \\
\text { Tiger } \\
\text { Vogel } \\
\text { Rechen } \\
\text { Fernglas } \\
\text { Sofa } \\
\text { Kamm } \\
\text { Auge } \\
\text { Frosch } \\
\text { Bürste } \\
\text { Dampfschiff }\end{array}$} & 516 & 53 \\
\hline & Sofa & 1,685 & 516 & & & 337 & 126 \\
\hline & Rechen & 1,112 & 57 & & & 444 & 19 \\
\hline & $\begin{array}{l}\text { Auge } \\
\text { Lampe }\end{array}$ & $\begin{array}{l}1,44^{8} \\
1,145\end{array}$ & $\begin{array}{r}279 \\
24\end{array}$ & & & $\begin{array}{l}572 \\
563\end{array}$ & $\begin{array}{l}109 \\
100\end{array}$ \\
\hline & Dampsfchiff & 857 & 312 & & & 401 & 62 \\
\hline & Ochse & 1,553 & 384 & & & 484 & 21 \\
\hline \multirow[t]{5}{*}{$12 / V I$} & Frosch & $1, \infty 09$ & 160 & & & $75^{8}$ & 295 \\
\hline & Kamm & 794 & 375 & \multirow[t]{4}{*}{$12 / \mathrm{VI}$} & & 259 & 204 \\
\hline & Bürste & $\begin{array}{r}815 \\
\end{array}$ & 354 & & & 386 & 77 \\
\hline & $\begin{array}{l}\text { Pinsel } \\
\text { Besen }\end{array}$ & $\begin{array}{l}1,091 \\
1,108\end{array}$ & $\begin{array}{l}78 \\
6 \mathrm{I}\end{array}$ & & & $\begin{array}{l}390 \\
245\end{array}$ & 218 \\
\hline & Handbeil & $\mathrm{x}, 188$ & 19 & & & 572 & 109 \\
\hline \multirow[t]{3}{*}{$30 / V I$} & Vogel & $I, 155$ & I4 & \multirow{2}{*}{$\mathrm{I}_{4} / \mathrm{VII}$} & & $5^{83}$ & 120 \\
\hline & Tiger & 1,275 & 106 & & & 436 & 27 \\
\hline & & 1,209 & $\begin{array}{r}40 \\
232\end{array}$ & & & $\begin{array}{l}440 \\
478\end{array}$ & 23 \\
\hline \multirow{4}{*}{$\mathrm{I}_{4} / \mathrm{VII}$} & Schuh & 1,445 & 276 & & & $1 7 \longdiv { 7 , 8 7 0 }$ & 1,645 \\
\hline & Rechen & 1,544 & 375 & & \multirow{3}{*}{\multicolumn{2}{|c|}{$\begin{array}{l}\text { Mean }=463 \\
\text { Median }=444\end{array}$}} & 96 \\
\hline & & 19) 22,209 & 3,992 & & & & \\
\hline & & 1,169 & 210 & & & & \\
\hline
\end{tabular}

Reactions to visual imagery equal or before median $=0$. 
SUBJECT SCHERREN

\begin{tabular}{|c|c|c|c|c|c|c|c|}
\hline Date & Vusual Image & $r$ & $V$ & Date & Simple Meaning & $T$ & $\nu$ \\
\hline \multirow{13}{*}{ 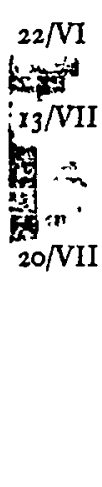 } & \multirow{13}{*}{$\begin{array}{l}\text { Krebs } \\
\text { Stern } \\
\text { Herz } \\
\text { Trommel } \\
\text { Spinne } \\
\text { Koffer } \\
\text { Flasche } \\
\text { Hirsch } \\
\text { Sabel } \\
\text { Traube } \\
\text { Engel } \\
\text { Facher }\end{array}$} & 07 & 5,140 & \multirow{11}{*}{$13 / \mathrm{VII}$} & \multirow{11}{*}{$\begin{array}{l}\text { Fliege } \\
\text { Facher } \\
\text { Finger } \\
\text { Herz } \\
\text { Fliege } \\
\text { Stern } \\
\text { Krebs } \\
\text { Koffer } \\
\text { Spinne } \\
\text { Trommel } \\
\text { Säbel } \\
\text { Flasche } \\
\text { Engel } \\
\text { Traube }\end{array}$} & & \\
\hline & & 4,537 & 130 & & & & 2 \\
\hline & & 3,370 & 1,297 & & & & \\
\hline & & 6,505 & $1,83^{8}$ & & & & \\
\hline & & 4,587 & 80 & & & 1,034 & 27 \\
\hline & & 2,531 & 2,136 & & & 1,080 & \\
\hline & & $\begin{array}{l}3,159 \\
3,4 I I\end{array}$ & $\begin{array}{l}1,400 \\
1,256\end{array}$ & & & 903 & \\
\hline & & 5,354 & 687 & & & 697 & \\
\hline & & 5,402 & $\begin{array}{l}735 \\
673\end{array}$ & & & $\begin{array}{l}561 \\
631\end{array}$ & 12 \\
\hline & & & 2,660 & & & $\begin{array}{l}969 \\
378\end{array}$ & \\
\hline & & & & & & 501 & 2 \\
\hline & & 12) 56,010 & 18,120 & & & 14) 10,644 & 2,692 \\
\hline & & 4,66 & 1,510 & & & $\begin{array}{l}\text { ean }=760 \\
\text { edian }=742\end{array}$ & 19 \\
\hline
\end{tabular}

Reaction to visual imagery equal or below median $=0$.

Subject Stappen

Words

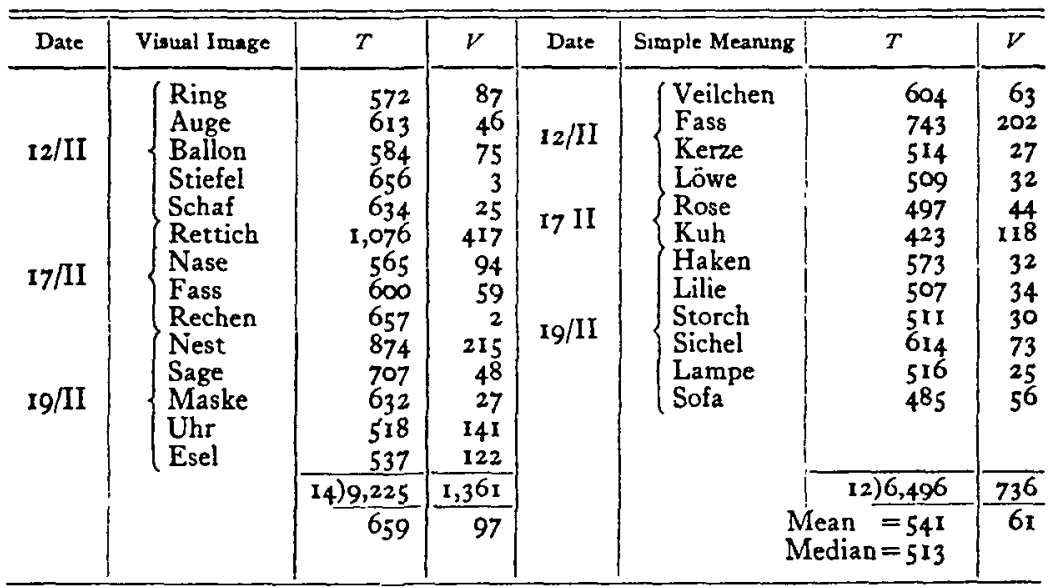

Reactions to visual imagery equal or below median $=0$.

reaction times in thousandths of a second. Under $V$, the variations from the mean.

At the bottom of each column the mean reaction times and mean variations have been calculated. The median for the reaction times to meaning have also been determined.

With but one exception, our nine subjects show a marked difference in their reactions to meaning and imagery. The 
Subject T

Words

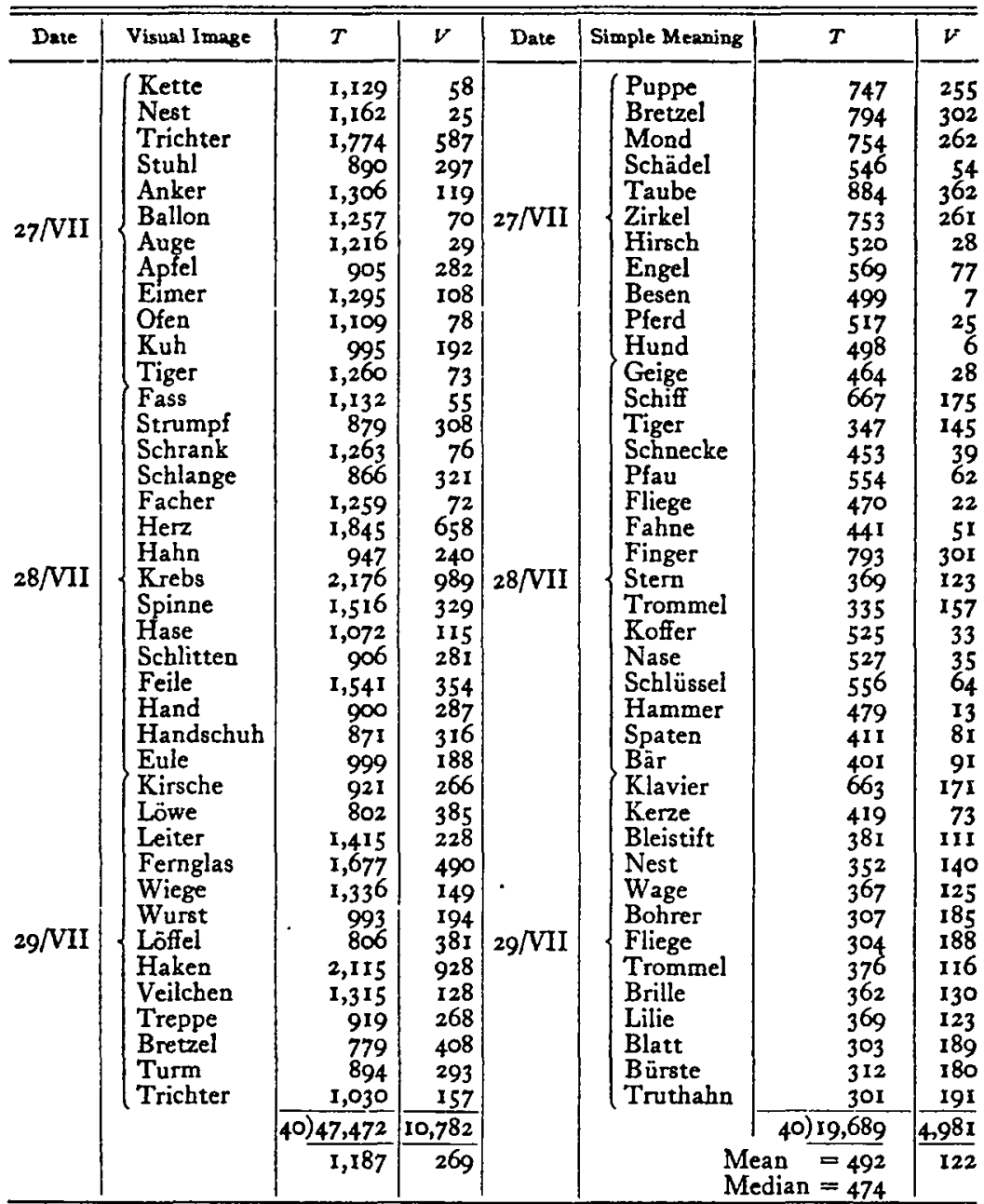

Reactions to visual imagery equal or below median $=0$.

one exception is not to be explained by individual difference in mental type, but rather by an anxiety to react as quickly as possible. At first he reacted to every nonsense word. He was then tried with pictures. Here again, every meaningless drawing elicited a reaction in spite of instructions. The reaction times at first varied around $100 \sigma$. Later he was 
asked to wait each time and make a judgment that he had fulfilled the task given him. Even under these instructions, he continued to react occasionally to nonsense words-the following reaction being very much retarded. He finally gave up the experiments. What would have resulted had he by practice become entirely free from erroneous reactions one cannot say. It would seem, however, more fair to a just conclusion to exclude rather than include his results in our summary. Leaving aside the results of this subject, the reaction times to visual imagery were all but one above the median of the reaction time to meaning. It is worthy of note that this single exception is the first recorded reaction of this subject. (He had made several practice series before.) Our subjects made 150 reactions in all. Were it merely a matter

Subject Marezoll

Wörter

\begin{tabular}{|c|c|c|c|}
\hline & $V_{1 s u a l}$ Image & Simple Meaning & $D$ \\
\hline 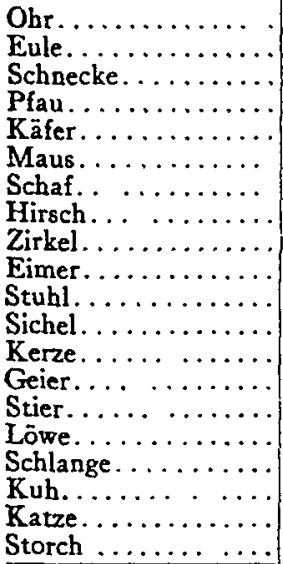 & $\begin{array}{r}1,308 \\
1,598 \\
1,374 \\
2,721 \\
3,868 \\
2,610 \\
1,309 \\
1,222 \\
1,210 \\
1,021 \\
947 \\
870 \\
1,187 \\
1,367 \\
988 \\
1,607 \\
1,292 \\
1,571 \\
1,146 \\
1,258\end{array}$ & $\begin{array}{l}508 \\
398 \\
676 \\
436 \\
841 \\
456 \\
697 \\
384 \\
406 \\
557 \\
425 \\
594 \\
638 \\
325 \\
458 \\
774 \\
761 \\
822 \\
576 \\
693 \\
\end{array}$ & $\begin{array}{l}+\quad 800 \\
+\quad 1,200 \\
+\quad 698 \\
+2,285 \\
+3,027 \\
+2,154 \\
+\quad 612 \\
+\quad 838 \\
+\quad 804 \\
+\quad 464 \\
+\quad 522 \\
+\quad 376 \\
+\quad 549 \\
+\quad 1,042 \\
+\quad 530 \\
+\quad 933 \\
+\quad 531 \\
+\quad 759 \\
+\quad 570 \\
+\quad 565 \\
\end{array}$ \\
\hline \multirow{2}{*}{ Storch $\ldots \ldots \ldots \ldots$} & 20) 30,474 & 11,425 & 19,259 \\
\hline & 1523.7 & 571.2 & 962.9 \\
\hline
\end{tabular}

of chance that reaction times to imagery should be longer than those to meaning we could find about 75 longer and 75 shorter. As a matter of fact, we find 149 longer and only one shorter. In spite then of the rather small number of reactions (conditioned by taking the introspective reports) there is over- 
whelming evidence to show that something more than chance has to do with the difference in reaction time to meaning and imagery. This difference is not due to the words used for imagery and meaning. Not only were the words in both cases representative of sensory objects but care was taken to repeat the same words in the two series. A table is given above comparing the reactions of one subject for meaning and imagery to the same words. Under $D$ is given the difference between the two. The reaction time to imagery is always longer than to meaning. With some of our subjects the results are not so unanimous, the meaning reaction being occasionally longer. This is to be explained mainly by the effects of practice, though something is no doubt due to accidental variation.

\section{(b) Introspective Data}

From the quantitative results that have just been given, it is evident that the subjects give a different response when told to react to meaning or imagery. Were we to stop with the quantitative results we would not know very much about the nature of that difference. Is meaning simply an early stage in the development of the image? Is it a vague confused image? Is it merely the realization of the power to visualize the object? Is it the tendency of a number of images to crowd into consciousness? What is the difference? There can be no doubt that a considerable difference exists and it is of great importance to find out precisely what it is. This can be done by an examination of the subjects' introspective reports of what they experienced during their reactions. The reports were taken down by dictation immediately after the reaction and then re-read to the subject to insure their accuracy. The originals are in German and will be given in German and in English when a complete account of all the experiments is published. 


\section{Consciousness of Meaning}

(1) The meaning has a general character.

Kerze: "There came to me at once the word 'Light.' This was not a determination of the meaning, but only another word for it. The meaning was entirely general, as if I should say a candle, that is, any candle-every possible candle." -Külpe, $9 /$ II.

(2) The universality of the meaning is not always absolute.

Ring: "As soon as I saw this word, I experienced an auditory motor stimulus, and immediately in connection therewith the understanding of that which the word signified. This was quite universal without being related to anything in particular-except the limitation to "fingerring.' I am distinctly conscious that a finger-ring was intended. I cannot remember an image of any such ring." -Külpe, 13/II.

(3) The meaning is at times felt to be incomplete, because of an unanalyzed consciousness of what the word signifies.

Schere: "At first, a feeling of familiarity was present and then a feeling of certainty that I know what the word signifies without having analyzed its meaning any further. First, during the reaction itself there came the further thought 'something with which one cuts.", -Moore, 9/VI.

Eule: "I knew that the word was something with which I am familiar and knew that from this point I could, at any time, go on and find its more specific meaning. Thereupon I reacted. In the word itself there was something presented to consciousness (mir gegeben) that I cannot further describe."-Frl. Marezoll, Io/VI.

\section{Consciousness of Visual Imagery}

(I) The image is particular.

Sofa: "I have a rather good image and 1 did not pronounce the word. I see with great precision the brown color and the form of the object-but not of the entire object. I could derive several concepts from this one image. It looks like a large reclining chair. The image would not do for all sofas."-Grüninger, 16/II.

(2) The image is at times schematic.

Herz: "I read the word 'heart' and apprehended its meaning. I remembered my task and sought after an image. I projected over the place of the card a heart of regular mathematical proportions. Only the contours were imaged, and these by such an airy line that I question myself whether I had a visual image at all or whether it was an ideal construction, such as one carries out in mathematical thinking."-Scherren, 13/VII.

(3) The image is at times incomplete in a different way.

(i) It is partial.

Rechen: "First, the meaning, then the image. Nevertheless, I reacted before the image was clear. I imaged a part of a rake. Already I have noted several times that I image the left lower parts of objects. Here I imaged a wooden rake." -Stappen, I7/II.

(ii) It represents a single definite character of an object.

Kuh: "I have the meaning and now I must have an image. I then look at an empty spot-no longer at the word. Then there appears the color of the animal. I see 'brown.' But a satisfactory, complete image, I do not obtain. I must exert myself even to obtain the color. I could not take the image for the meaning. I cannot read anything more out of the image than 'brown'- never the meaning 'cow." -Grüninger, 16/11. 
Conscrousness of Menunne

(4) The meaning never has sensory characteristics but sather a conceptual determination.

Geier: "A moment passed before I found the meaning. No auditory-kinasthetic image was present. I knew that it was something that hovers over mountains in the air-even though I did not see the mountains. Visually I imaged only a pair of extended wings and knew that something belonged between them." -Frl. Marezoll, I4/V.

Veilchen: Immediately after the word appeared, I had an auditory-kinæsthetic image of it-as I pronounce it. 'Veilchen,' and in connection therewith a knowledge of its meaning (Ein allgemeines Bedeutungswissen), that I can thus explain: a definite species of flower. I dare say that it is this which makes up the content of the meaning what I actually know about this object during the experiment.-Külpe, $18 / \mathrm{V}$.

(5) The meaning is often expressed in terms of a definition of general application.

Dampfachiff: Immediately on the exposition of the word, auditory-kinzsthetic image thereof, and a realization of the meaning in the sense of 'a means of transport by water.' This time there was no trace of any image.-Külpe, r6/II.

(6) The meaning is never localized.

\section{Consciousness of Visual Imugery}

(4) The image manifests degrees of brightness, color and clearness.

Rose: "Immediately after the word came I had the auditory-kinasthetic image of the word and thereupon an understanding for its general signification. Then first came an image-the image of a blossom. Almost nothing of the stem was seen. Colorless, mere differences of brightness in the blossom and the leaves were perceived. A full blown rose. The common form. Image and meaning did not cover each other." -Külpe, 16/II.

Krug: Meaning then the visual image. It was an earthenware jug, bellied out in front-antique as if it had just been dug up.-Lehner, 7/VII.

(5) The image is often described in sensory terms that roould fit only a oery definite object.

Rettich: This time there came to me the image of a radich of medium size. I saw clearly the little hollows in its skin filled with dirt and myself in the attitude in which I cultivate this beautiful variety in my wife's garden. All at once there came to me a poem of Mörike. It is entitled 'The Radish.'-Iehner, 16/II.

(6) The image has often a definite position.

Schuh: I had an indistinct image of a laced shoe-the point to the right somewhat behind the plane of the word. A confused consciousness of meaning was also immediately present, which did not coincide with the image. The meaning was even more general than foot covering. It had somewhat the sense of a piece of clothing without relation to a part of the body.-Külpe, 23/II. 
Consciousness of Meaning

(7) The meaning is alevays pertinent to the woord.

(8) The meaning is never looked upon as superfiuous.

(9) The meaning is always present.

(10) The meaning leads regularly to the image.

Nearly always the subjects report the meaning as coming first.

(II) The meaning comes spontaneously. Cases enough have already been cited to make this evident. Only occasionally, where the word is read incorrectly, is any effort required to bring out this meaning.

\section{Conscrousness of Visual Imagery}

(7) The image is sometimes recogrized as not strictly pertaining to the word.

Rettich: The word appeared very strange to me. I think I read something like 'Bettish.' Only later did I get the correct meaning. There came a visual image. The image did not really represent a radish but rather a kind of turnip.

(8) The image is oflen regarded as unnecessary and of secondary importance.

Ochs: I first understood the word as something familiar, as something that I knew what it was. A further analysis of the meaning did not take place. Under the influence of the task, my attention was directed to experiencing an image and then arose the head of an ox with his horns as drawn in the pictures for these experiments.-Moore, $12 / \mathrm{VI}$.

Fass: Immediately after looking at the word an auditory-kinzsthetic representation and understanding of its general signification in the sense of a spatial measure. There came also-altogether fleetingly a weak image with a pair of hoops lying on the ground-wholly accessory as if a schema.-Külpe, I6/II.

(9) The image is often lacking.

Such cases could be multiplied indefinitely. Some have already been given.

(10) The image is only occusionally present before the meaning.

Kuh: I believel the image came firstwholly undefined. Very soon thereafter the meaning, immediately after which the reaction.-Stappen, 17/II.

The image must ofien be sought.

Flasche: I had the feeling of a considerably retarded flow of imagery, and perceived clearly that I was sharply concenstrated upon my task. I then imagined that I went through Amalien Street and

1 These cases are very rare. I have found them only with this subject and when he does mention them, it is always with reserve. He says ' $I$ believe' indicating that he is not sure of the observation. 
had the task to represent to myself a bottle. The representation succeeded but rather poorly. Only the image of the material (glass) and the long form was clear.-Iehner, 3 /VII.

A careful consideration of these results will show that the difference between meaning and visual imagery does not consist in any possible difference in the original imagery itself.

If meaning were an early stage in the development of the visual imagery, it might be possible to explain in this way the difference in the reaction times to the two events. A candid consideration of the introspections shows that this is not the case. The universality of the meaning cannot be pictured and is something quite different from the schematism of the image. The incompleteness of the image with a fragmentary character and washed out coloring differs profoundly from the imperfect unanalyzed embryonic stage of the meaning. The image has sensory characters which cannot be ascribed to the meaning-the meaning cognative characters which are utterly foreign to the image. The meaning is a 'knowing' suigeneris; the image is a sensational element with its own specific character.

The meaning is not the potentiality to visualize. It may have an element of potentiality about it, but it always has an element of actuality which extends from the unanalyzed knowledge expressed by the phrase: "I know what that is" - to the more perfect conception expressed by a definition. The potentiality of the meaning when present is not the same for all meanings. It is a definite potentiality in which the elements of a definition of the object are in subconsciousness. It is not the potentiality to visualize, for the potentiality to visualize ( $\mathrm{I}$ ) depends on a meaning to determine what is to be visualized; (2) results in something different from the actualization of the meaning. The actualization of the meaning leads to the consciousness of a definition which may not even be accompanied by imagery of any kind whatever.

Nor is imagery the tendency of a number of images to 
crowd into consciousness. That tendency is sometimes pre-sent especially with one of our subjects, but by him it was recognized as something that came after the meaning. ${ }^{1}$

Meaning is often present and one is definitely conscious of it without being conscious of a tendency of images to crowd into consciousness. Meaning is a consciousness of knowledge that has definite characters foreign to the images that tend to crowd into consciousness. Furthermore, where images do crowd into consciousness they have to be known. This knowledge of what the image represents cannot be explained by another image which would itself have to be known.

Meaning, therefore, appears to be a conscious process sui generis distinct from imagery.

\section{Consciousness of Purpose and Kinfesthetic IMAGERY}

\section{(a) Quantitative Results}

The instructions to the subject indicate sufficiently the nature of the investigation in this section of the work. These instructions were as follows:

Sie werden nach einem Signal ein Wort zu sehen bekommen. Ich bitte Sie zu reagieren wenn Sie die Bedeutung des Wortes im Hinblick auf den Gebrauch oder die Funktion des damit bezeichneten Gegenstandes erfasst, bzw., wenn Sie eine kinaesthetische oder kinaesthetisch-optische Vorstellung davon gehabt haben.

The words chosen for reaction stimuli in this set were not merely capable of being visualized but represented objects that most of us have often handled as: brush, bell, hat. To represent a word like 'lion' by a kinæsthetic image is to some subjects a very difficult task. Consequently a more appropriate set of words was chosen. Even under the most favorable conditions the kinæsthetic image comes far too late to account for the meaning. It might, however, be claimed that such an image is identical with the consciousness of the purpose of an object. Accordingly the comparison was made between reactions to the consciousness of purpose and those

${ }^{1}$ Cf. supra, p. 178 . Subject Lehner. 
to the awareness of a kinæsthetic image which concerned the object itself. Mere verbal images were excluded. Seven subjects took part in this set of experiments.

The results are shown in the accompanying tables:

Subject Grüninger

Words

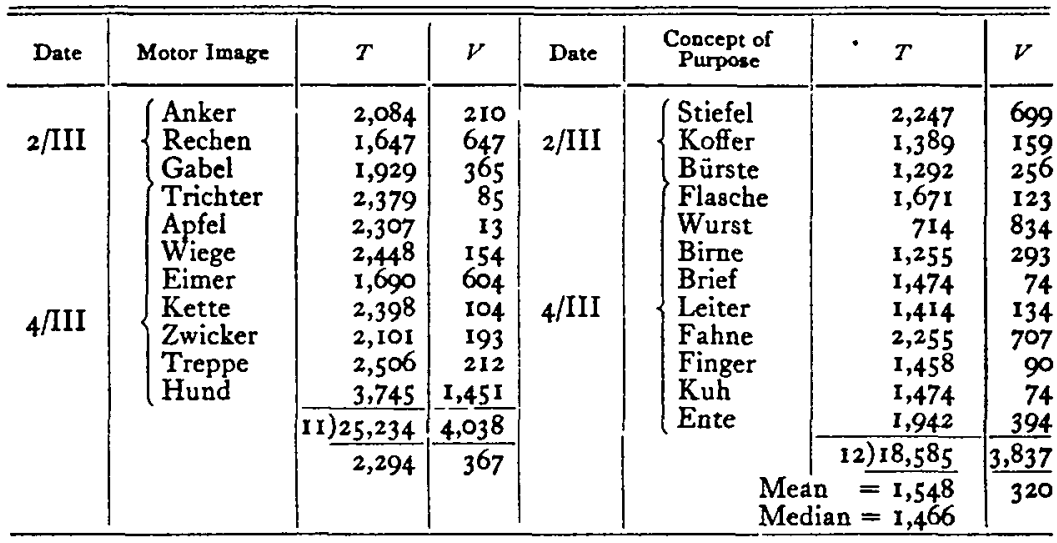

Number of times median for concept exceeds reaction time for imagery $=0$.

SUbject KüLPE

Words

\begin{tabular}{|c|c|c|c|c|c|c|c|}
\hline Date & $\begin{array}{l}\text { Kinzesthetic } \\
\text { Image }\end{array}$ & $T$ & $V$ & Date & $\begin{array}{l}\text { Concept } \\
\text { of Purpose }\end{array}$ & $T$ & $V$ \\
\hline \multirow[t]{10}{*}{$27 / 11$} & \multirow{10}{*}{$\begin{array}{l}\text { Ring } \\
\text { Sichel } \\
\text { Ring } \\
\text { Rechen } \\
\text { Bleistift } \\
\text { Würfel } \\
\text { Lampe } \\
\text { Pickel }\end{array}$} & 1,100 & $45 \mathrm{I}$ & \multirow{5}{*}{$27 / \mathrm{II}$} & \multirow{8}{*}{$\begin{array}{l}\text { Stiefel } \\
\text { Auge } \\
\text { Haken } \\
\text { Hammer } \\
\text { Bürste } \\
\text { Gabel } \\
\text { Feile } \\
\text { Uhr } \\
\text { Stiefel }\end{array}$} & 804 & 306 \\
\hline & & 1,416 & 135 & & & $1,180^{\circ}$ & 70 \\
\hline & & 1,332 & 219 & & & 771 & 339 \\
\hline & & 1,823 & 272 & & & 1,822 & 712 \\
\hline & & 1,227 & 324 & & & 1,346 & 236 \\
\hline & & 2,579 & 1,028 & \multirow[t]{3}{*}{$2 / 1 I I$} & & $x, 165$ & 55 \\
\hline & & $\begin{array}{l}1,298 \\
\mathrm{r}, 638\end{array}$ & $\begin{array}{r}253 \\
87\end{array}$ & & & $\begin{array}{r}1,153 \\
808\end{array}$ & $\begin{array}{r}43 \\
302\end{array}$ \\
\hline & & 8) 12,413 & 2,769 & & & 944 & 166 \\
\hline & & I.55I & 346 & & & 9) 9,993 & 2,229 \\
\hline & & & & & \multicolumn{2}{|c|}{$\begin{aligned} \text { Mean } & \frac{99,993}{=1,110}\end{aligned}$} & 247 \\
\hline
\end{tabular}

Number of times median for concept exceeds reaction time for imagery $=\mathbf{I}$.

With all of our subjects the mean for reaction time to kinæsthetic imagery is longer than that to the concept of purpose. Examining these results critically we find that with some of our subjects in spite of the small number of 
SUBject LeHNER

Words

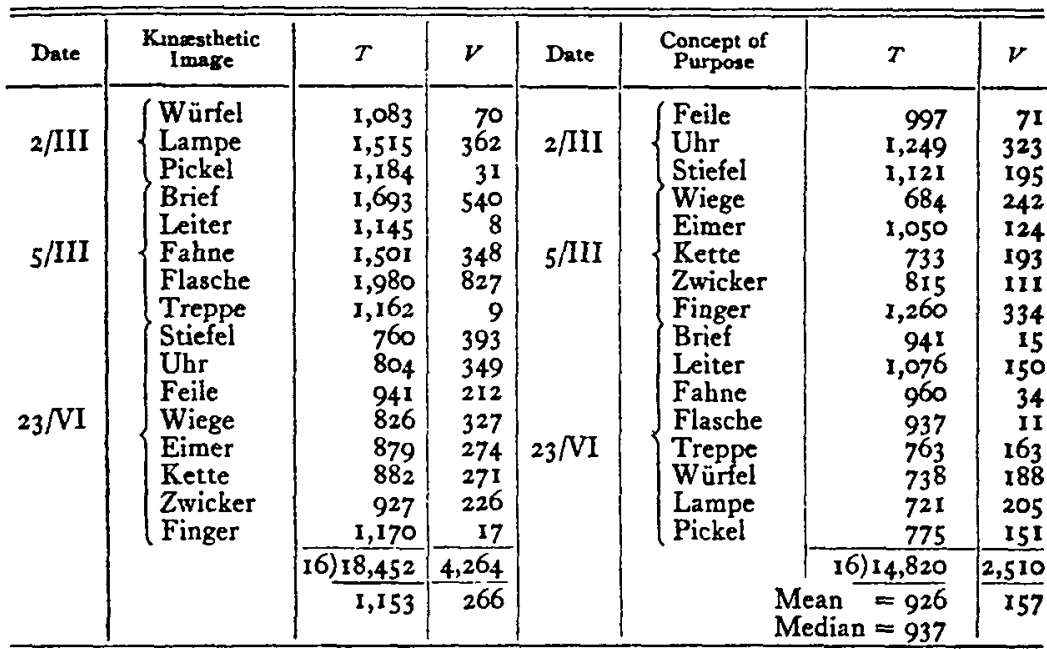

Number of times median for concept exceeds reaction time for imagery $=6$.

Subject Marezoll

Words

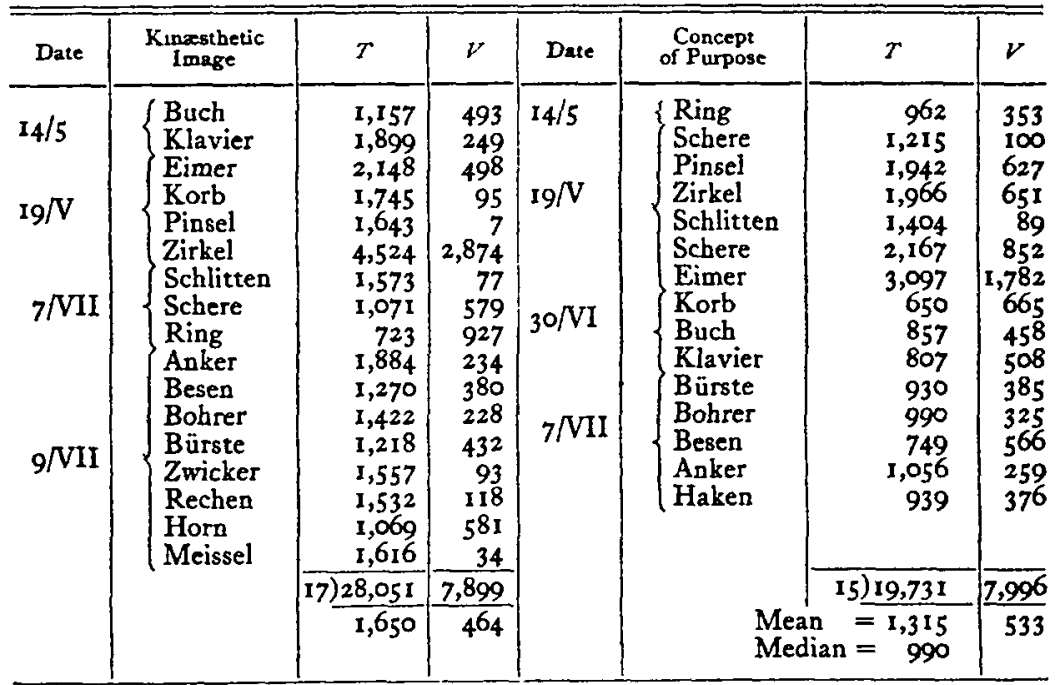

Number of times median for concept exceeds reaction time for imagery $=0$. 
Subject MOORE

Words

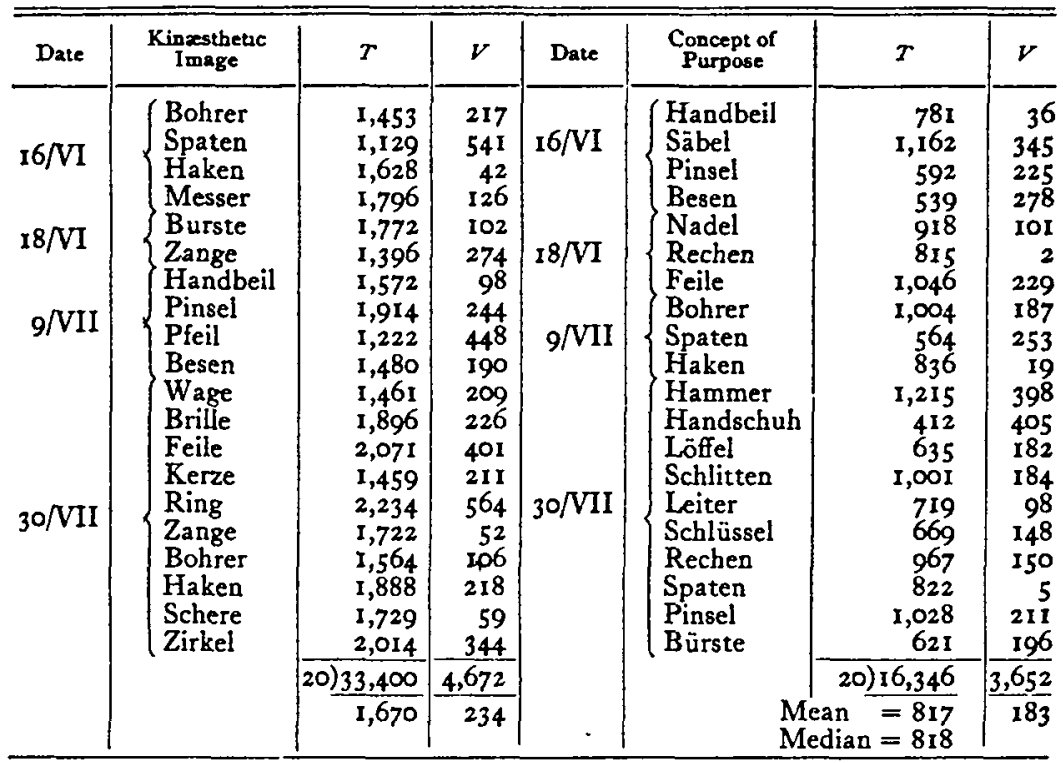

Number of times median for concept exceeds reaction time for imagery $=0$.

Subject Stappen

Words

\begin{tabular}{|c|c|c|c|c|c|c|c|}
\hline Date & $\begin{array}{l}\text { Kunazsthetuc } \\
\text { Image }\end{array}$ & $T$ & $V$ & Date & $\begin{array}{l}\text { Concept of } \\
\text { Pupose }\end{array}$ & $T$ & $V$ \\
\hline \multirow[t]{3}{*}{$28 / \mathrm{II}$} & \multirow[t]{3}{*}{$\begin{array}{l}\text { Kerze } \\
\text { Haken } \\
\text { Burste } \\
\text { Würfel } \\
\text { Sense }\end{array}$} & $\begin{array}{r}4,308 \\
528 \\
644 \\
465 \\
1,024\end{array}$ & $\begin{array}{r}2,915 \\
865 \\
749 \\
928 \\
369\end{array}$ & \multirow[t]{3}{*}{$28 / \mathrm{II}$} & \multirow[t]{3}{*}{$\begin{array}{l}\text { Auge } \\
\text { Säge } \\
\text { Sichel } \\
\text { Gabel } \\
\text { Feile }\end{array}$} & $\begin{array}{r}1,199 \\
682 \\
697 \\
814 \\
362\end{array}$ & $\begin{array}{r}449 \\
68 \\
53 \\
64 \\
388\end{array}$ \\
\hline & & 5) 6,969 & 5,826 & & & 5) 3,754 & 1,022 \\
\hline & & 1,393 & 1,165 & & & $\begin{array}{l}\text { Mean }=750 \\
\text { Median }=697\end{array}$ & 204 \\
\hline
\end{tabular}

Number of times median for concept exceeds reaction time for imagery $=3$.

experiments we can say definitely that the concept of purpose comes quicker than the kinæsthetic imagery. With these subjects the median for the concept of purpose was shorter than everyone of the reaction times to kinæsthetic imagery. With one subject, one out of eight reactions to kinæsthetic imagery was shorter than the median; with another two out of 
SUBject TaNkBäuser

Words

\begin{tabular}{|c|c|c|c|c|c|c|c|}
\hline Date & $\begin{array}{c}\text { Kinzesthetac } \\
\text { lmage }\end{array}$ & $T$ & $V$ & Date & $\begin{array}{l}\text { Concept of } \\
\text { Purpose }\end{array}$ & $T$ & $\boldsymbol{v}$ \\
\hline \multirow{29}{*}{$30 / \mathrm{VII}$} & \multirow{29}{*}{$\begin{array}{l}\text { Bohrer } \\
\text { Schlüssel } \\
\text { Trichter } \\
\text { Bleistift } \\
\text { Trommel } \\
\text { Brille } \\
\text { Rechen } \\
\text { Tasche } \\
\text { Wage } \\
\text { Hammer } \\
\text { Handschuh } \\
\text { Besen } \\
\text { Dolch } \\
\text { Horn } \\
\text { Auge } \\
\text { Brunnen } \\
\text { Geige } \\
\text { Fass } \\
\text { Hahn } \\
\text { Beil } \\
\text { Messer } \\
\text { Lampe } \\
\text { Koffer } \\
\text { Buch } \\
\text { Hobel } \\
\text { Handbeil } \\
\text { Schuh } \\
\text { Ofen }\end{array}$} & 1,492 & 231 & \multirow{18}{*}{$30 / \mathrm{VII}$} & \multirow{27}{*}{$\begin{array}{l}\text { Klavier } \\
\text { Bürste } \\
\text { Fernglas } \\
\text { Haken } \\
\text { Leiter } \\
\text { Kerze } \\
\text { Pickel } \\
\text { Zange } \\
\text { Ring } \\
\text { Schlitten } \\
\text { Feile } \\
\text { Spaten } \\
\text { Brief } \\
\text { Anker } \\
\text { Eimer } \\
\text { Hut } \\
\text { Flasche } \\
\text { Glocke } \\
\text { Fächer } \\
\text { Finger } \\
\text { Fahne } \\
\text { Meissel } \\
\text { Korb } \\
\text { Kette } \\
\text { Kamm } \\
\text { Schrank } \\
\text { Sense } \\
\text { Pfeil } \\
\text { Nadel }\end{array}$} & 1,314 & 456 \\
\hline & & 939 & 322 & & & 749 & 109 \\
\hline & & 1,527 & & & & 749 & 109 \\
\hline & & 1,367 & 106 & & & 1,069 & 211 \\
\hline & & 1,088 & 173 & & & 829 & 29 \\
\hline & & 1,903 & 642 & & & 885 & 27 \\
\hline & & $\begin{array}{l}1,327 \\
1,255\end{array}$ & $\begin{array}{r}0 \\
6\end{array}$ & & & $\begin{array}{l}1,071 \\
1,816\end{array}$ & $\begin{array}{l}213 \\
95^{8}\end{array}$ \\
\hline & & 1,378 & 117 & & & 785 & 73 \\
\hline & & 1,005 & 256 & & & 600 & 258 \\
\hline & & $1,15 \overline{8}$ & 103 & & & 763 & 95 \\
\hline & & $\begin{array}{r}1,173 \\
855\end{array}$ & 88 & & & 554 & 304 \\
\hline & & & 406 & & & 554 & 304 \\
\hline & & $\begin{array}{l}1,011 \\
2,334\end{array}$ & 250 & & & 739 & II \\
\hline & & $\begin{array}{l}2,334 \\
2,216\end{array}$ & $\mathbf{I}, 073$ & & & 1,114 & 256 \\
\hline & & $\begin{array}{r}2,216 \\
694\end{array}$ & $\begin{array}{c}955 \\
567\end{array}$ & & & $\begin{array}{l}824 \\
976\end{array}$ & $\begin{array}{r}34 \\
118\end{array}$ \\
\hline & & 2,006 & 745 & & & 717 & 141 \\
\hline & & 2,082 & 821 & & & 648 & 210 \\
\hline & & 1,576 & 315 & & & 1,006 & 148 \\
\hline & & 831 & 430 & \multirow{8}{*}{$31 / V I I$} & & 875 & 17 \\
\hline & & 883 & 378 & & & 834 & 24 \\
\hline & & 797 & 464 & & & 952 & 94 \\
\hline & & 1,009 & 252 & & & 817 & 41 \\
\hline & & $1, \infty 07$ & 254 & & & 816 & 42 \\
\hline & & 707 & 554 & & & 637 & 221 \\
\hline & & 848 & 413 & & & 776 & 82 \\
\hline & & 849 & 412 & & & 700 & 158 \\
\hline & & 28) 35,317 & 10,665 & & & 720 & 138 \\
\hline & & 1,261 & 381 & & & 29) 24,889 & 4,989 \\
\hline & & & & & & $\begin{array}{r}=85^{8} \\
\operatorname{lian}=816\end{array}$ & 172 \\
\hline
\end{tabular}

Number of times median for concept exceeds reaction time for imagery $=2$.

twenty-eight. With one of our subjects the matter looks a little doubtful; six out of sixteen are shorter than the median. With another subject ${ }^{1}$ the results are too few and scattered to give any quantitative basis for judgment.

The question is one where individual differences are likely to play a part. Those who readily form kinæsthetic imagery may be able to obtain such an image more quickly than they can think of the purpose of the object. To what extent this is true cannot be decided from the present results. ${ }^{2}$

1 It was impossible to get more experiments from this subject. He left the day after the series above reported and did not return in the summer semester. They are more of the nature of a preparatory series than final results.

2 When a short abstract from this paper was read last December at the meeting 
Taking all the results together only 12 out of Io5 reactions to kinæsthetic imagery were shorter than the median of the various subjects' reaction-times to the concept of purpose.

\section{(b) Introspective Data}

Turning now to the introspective results, we find that the concept of purpose and the kinæsthetic image are very clearly differentiated. The concept of purpose differs from the simple meaning in that it does not come with the same necessity. It is the result of the subject's task-not of the mere exposition of the stimulus. The same is true of the kinæsthetic image. Both follow upon the awareness of the simple meaning. Neither is a necessary prelude nor a sequence of the other. The task "image" or "concept" is the main factor in determining which is to appear.

The following are some of the more noteworthy introspective differences between the two.

(1) The concept of purpose is expressed in non-sensory conceptual terms.

Zwicker: "I imaged my own eye glasses and had clearly a consciousness of concave glasses. I was further conscious of the fact that these glasses must refract the rays of light according to a definite law that the image may still fall upon the retina-even though the lens is incapable of doing it this service. I then formulated the purpose of eye-glasses as: 'The correction of an error of refraction." "Lehner, 5/III.

(2) The concept of purpose sometimes inooloes the consciousness of the relation of the object to other things.

Gabel: "Immediately after the appearance of the word an auditory-kinzsthetic image thereof. Then came the know-
(1) The kinasthetic image always describes some kind of act inooloing a use of the muscles.

Sichel: "Immediately after the word appeared I had an auditory-kinasthetic image of it. Following this I constructed a visual and weak kinzsthetic image thereof in this manner. I held a sickle in my right hand and made movements therewith as if I were cutting grass. Thereupon I reacted."-Külpe, 2/III.

(2) This was not noted in the description of the kinasthetic imagery.

of the Southern Society for Philosophy and Psychology, Professor Ogden stated that he had reported some years ago at one of the meetings a series of experiments similar to the present in all details. He never published his results, but they were identical with my own. In the interests of a better insight into individual differences it is to be hoped that Professor Ogden will some day give us the advantage of his unpublished results. 
ledge that the fork is an instrument for eating, accompanied by a weak visual image of a fork. I was also conscious that 'fork' stands in relation to 'knife."'Kütpe, 2/III.

(3) The concept of purpose though often restricted to one of oarious possible ends has alvays a certain generality.

Kette: "I pictured to myself a tolerably strong chain and remembered from the days of my youth that such chains were used to tie animals in their stalls. I saw the whole situation of that day rise up before me."-Lehner, 5/III.

(4) The consciousness of purpose seldom stops with a means but rests in a concept conceioed of as the object's end.

Uhr: "Immediately after the appearance of the word I had an auditory-kinæsthetic image, then the thought: 'The clock must be wound up!' and then the further thought: 'The clock tells the time!' Then I reacted. Weak visual image of a clock on a wall."-Külpe, 2/III.

(5) The concept of purpose, even though delayed, comes as a natural development of thought about the object.
(3) The kinasthetic image is often perfectly definite and limited 20 an indioidual act in a certain time and place.

Pickel: "I imaged a pick-ax, such as is used for working hard ground and saw myself in my garden in the act of lifting it in the air. The consciousness of the purpose of a pick-ax is a psychological process which cannot be identified with the act of lifting it."-Lehner, $2 / V$.

Wiege: "The meaning aroused the image of a cradle. I go back in thought to my childhood and feel how I rock my brother. The kinæesthetic image in this case contains a great part of the purpose." -Grüninger, 4/III.

(4) The kinasthetic image regularly concerns an art which is a means to the object's end.

Lampe: "I imaged the lamp that I use in my dwelling, and saw clearly that it did not burn brightly enough, and then imaged the turning up of the wick. The kinxsthetic image of the movement cannot be identified with the consciousness of purpose."-Lehner, 2/III.

Trichter: "Immediately after the simple meaning of the word, I had the visual image of a funnel and then the kinzsthetic image of laying hold of it with my right hand and placing it over an opening. Here also the kinzsthetic image falls short of being the fulfilment of the purpose. For I think that the funnel is the instrument by means of which I pour fluid through an opening, and my image is only the placing of the funnel in the opening."-Grüninger, 4/III.

(5) The kinasthetic image is ofters forced and is superfiuous to the understanding of the function of the object. 
Handbeil: "I soon understood the word, but the simple consciousness of meaning was forced into the background of consciousness by the task. I can express this simple consciousness of meaning by the sentence: ' I know well what that is!' Then I asked myself under the influence of my task: 'What purpose does it serve?" Then there came to me the clear concept that it is of use in cutting wood. With this concept of purpose were some broken, confused words. I do not know whether they were German or English. There was also a dark blurred image of an island in Lake George, where I have often cut wood in summer." Moore, 16/VI.

(6) The concept of purpose, though at times more or less restricted, never miscarries entirely.
Fahne: It was rather difficult for me to connect a kinzsthetic image with the word. At first I imaged a flag as I saw one recently waving on a little tower in Leopold Street. But I said to myself at once, "This waving is not a kinæsthetic image.' Then I imaged to myself how I would place this flag on the little tower. That the purpose of the flag is not covered by my motor image of it, goes without saying."-Lehner, 5/III.

(6) The kinasthetic image is not always pertinent to the purpose of the object.

Bohrer: "Again the meaning first and then a visual image of the object-of a whole situation. I attempted to screw a drill through the wall, and instead of that I lifted the whole wall with the drill."-Frl. Marezoll, $9 /$ VII.

\section{Meaning and the Word}

(a) Quantitative Results

In the perception of the meaning of words, subjects often spoke of the meaning being associated with an auditorykinæsthetic verbal image of the word itself. No attempt was made to find out by reaction time the temporal relations of the verbal image and meaning in the perception of printed words. From the introspective results no definite answer can be obtained. The two are so close together that they appear simultaneous. One might, however, surmise that since the word must be read, in order that it may be perceived and understood, verbal sensations or verbal imagery are likely to come prior to understanding.

On account of the close connection with the sensations involved in reading and the understanding of printed words, such material presents no little difficulty in studying the 
necessary relations between verbal imagery and meaning. Pictures seemed to offer a more favorable material for study. If meaning is the kinæsthesis of speech, then the knowledge that a picture before me represents a tree should come when I name the picture and not before. A series of reaction times for the naming of pictures and perceiving the meaning of pictures should give approximately identical results. Three of our subjects took part in these experiments.

With all three subjects there is strong evidence that in general it takes longer to react to the word than to the meaning. The means for reaction to the word are, in every case, longer than those for meaning. This excess is also

SUbject Legner

Pictures

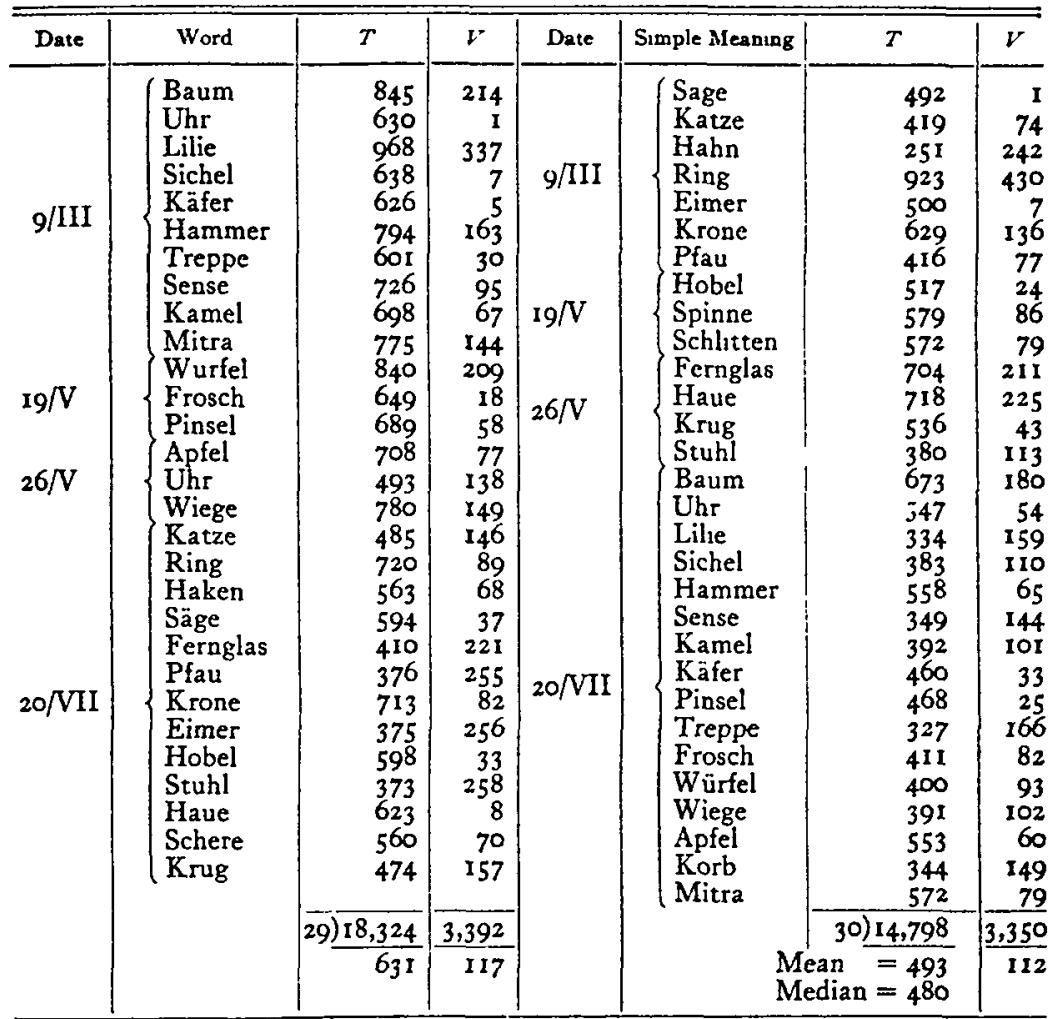

Number of times median for meaning exceeds reaction time $=6$. 
SUBject KüLPE

Pictures

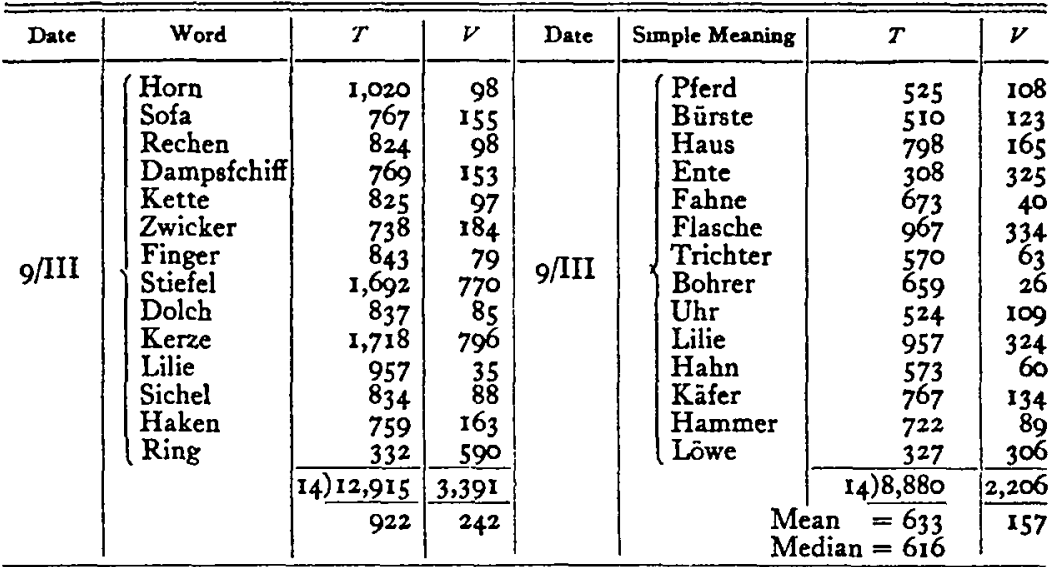

Number of times median for meaning exceeds reaction time to word $=1$.

Subject Marezoll

Pictures

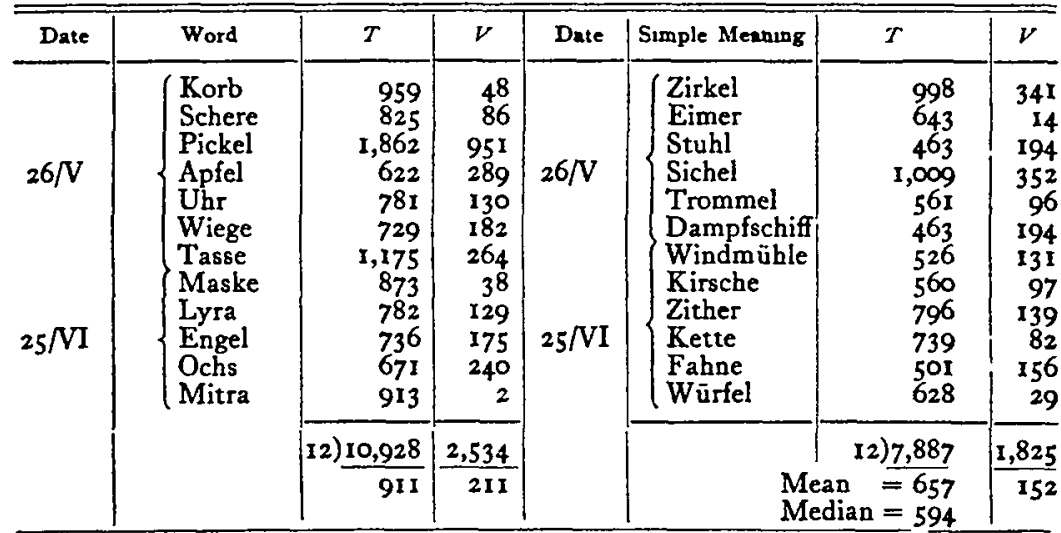

Number of times median for meaning exceeds reaction time for word $=0$.

greater than the mean variation. With one subject in 29 reactions to words, only 6 were shorter than the median for meaning; with another, 1 in 14; with another, $O$ in 12.

\section{(b) Introspective Data}

Turning to the introspective results we find them in accordance with the quantitative measurements. Time and 
time again, whether the task were meaning or word, the same sequence of events was perceived, viz., (I) meaning, (2) word, (3) reaction. Often, however, when the task was meaning, the word was reported as coming during or after reaction.

Some special points of difference between the word and the meaning are given below.

(1) The meaning leads to the roord-the designation of the picture.

Frosch:"The meaning was first present. I felt a strong striving for the word, as it were from various sides of the drawing. The reaction followed after the entrance of the word."-Lehner, $9 / \mathrm{V}$.

(2) A meaning cannot be lacking if the subject names the picture-no matter what the task.

(3) The meaning is what it is by its own right. It is never said to have a meaning.

Pferd: "Immediately after I saw the picture I experienced a tone of familiarity and knew what this picture represented. At the same time, with the reaction came the word 'Pferd.' I did not react to the word. The tone of familiarity was related not to the picture, but to what it signified. The picture was a symbol of real objects and its signification consisted herein, viz.-to point to them."Külpe, $9 / I I I$.

(4) The meaning is sometimes designated by a word which is known to be inappropriate.

Lilie: "First I recognized in the picture a flower, then I named it by mistake 'Tulpe.' I knew that 'Tulpe' did not fit the picture. Then through the form of the flower, etc., I was occasioned to say "Glockenblume."-Lehner, 9/III.
(I) The word neoer leads to the meaning.

(2) The word may be lacking when the task is meaning.

Eimer: The word did not appear at all. Various memories were in the background of consciousness.-Frl. Marezoll, $26 / \mathrm{V}$.

(3) The word may have a special meaning of its own; e. g., the word has a more general meaning than that of the picture.

Engel: "Immediately a memory image. After this image came the word. I knew that the meaning of the word was more general than that of the picture."-Frl. Marezoll, 25/VI.

(4) The soord is never designated by a meaning. 


\section{Influence of the Observer's Attitude}

When a short abstract of this paper was read last December at the meeting of the Southern Society of Philosophy and Psychology, it was suggested that the difference in reaction time to meaning and imagery is to be explained by a difference in the attitude of the subject. He reacts quicker when told to react to meaning, not because the meaning is something different from the imagery but because he himself assumes a different attitude.

This objection implies that there is no real difference between meaning and imagery, but that when we call them by different names the subject, for some obscure reason, assumes such a different attitude that it markedly influences his reaction time. The objector in other words does not wish to admit a difference between meaning and imagery, and refers the difference in reaction time to an unexplained and perhaps inexplicable mystery.

To say the least, this explanation is highly improbable. For supposing there is no such thing as a special 'meaning process' and that the accruing image is identical with the meaning, then the task of the subject in the two sets of reactions is really identical. It is simply called by different names. If that were the case, then the subject ought (I) to have a real difficulty in distinguishing his two tasks. (2) $\mathrm{He}$ ought to give introspective reports identifying the two procedures. (3) The reaction times ought to be identical within the limits of the probable error.

None of these things were so, but on the contrary (I) The tasks were readily distinguished. (2) The introspective reports clearly separate the two processes. (3) The reaction times are markedly different.

All this tends to render highly improbable, if not impossible, the explanation which suggested that the difference in the reaction times is not to be explained by a real difference in the tasks, dependent on a difference between meaning and imagery, but is due entirely to the difference in the attitude of the subject. In fact, it is very hard even to imagine a 
mental mechanism which would produce two separate attitudes with such different effects in the reaction-times, if that to which the subject takes an attitude is in both cases merely one and the same thing that the experimenter calls by a different name.

Let us, however, go a step further. Our subjects reacted to visual and kinæsthetic images. If we wish to compare the reaction times in this case we will find them markedly different. Is it possible to explain that difference by a difference in the attitude of the subject?

If we should argue visual imagery is distinct from kinæsthetic (I) because the subject distinguishes two different tasks when told to react to the one or the other; (2) because the introspective reports clearly separate the one from the other; (3) because the reaction times to visual imagery are much shorter than to kinæsthetic imagery, no one would doubt the validity of the argument. When, however, the same argument is made in regard to imagery and meaning, it is called in question and the attempt is made to explain away the difference by ascribing it to a difference in the attitude of the subject. If, however, the difference in the attitude of the subject is not the real explanation in the latter case, but a real difference between visual and kinæsthetic imagery, then this difference in the attitude of the subject cannot, without any more ado, explain the shorter reaction time for meaning as compared with imagery.

Furthermore, the difference in attitude itself must be explained. Granted that there is a difference in attitude, what is the most likely explanation for the fact? The first thing that comes to mind is that in the two sets of conditions the subject is taking an attitude to two different things. If that is the case then, meaning and imagery must be distinguished. But how distinguished-as two different mental processes or as two aspects of one and the same process?

In the sequence of events that follow the exposition of the stimulus word, there may be, if you wait long enough, not only visual but also kinæsthetic imagery. Are these aspects of one and the same mental processes, or specifically dif- 
ferent items in a definite series of events? Reasons have already been given for distinguishing them. These reasons point to events that are qualitatively distinct, and the distinction can scarcely be called in question. But the very same reasons point to meaning as qualitatively distinct from imagery. When, furthermore, one considers the fact that in the understanding of words the meaning process is never absent, but that visual and kinæsthetic imagery may both be lacking, there is an added reason why meaning should not be identified with an aspect of visual or kinæsthetic imagery.

Furthermore, a difference in the attitude of the observer cannot be made the sole reason for the difference in the reaction times.

(i) In the set of experiments referred to in the beginning, the subject's task was to observe and remember a series of words, pictures or objects. Nothing was said about attending to meaning or imagery. He had simply to report what he had experienced-whatever that might be. Here the question of a difference in the "set" of the observer does not enter at all. In these experiments, the subjects reported that in the perception of words, meaning preceded imagery. This suggested the problem of an objective test of the accuracy of the introspection. The reaction time experiments followed, and confirmed with entire satisfaction the introspections of the earlier series.

(ii) In the reaction time experiments no matter what the task-whether the subject is in the meaning attitude or the image attitude, he regularly reports meaning as coming prior to imagery. If the difference in the 'set' of the observer were the sole reason for the difference in reaction time, we should not expect that no matter what his 'set' he would nevertheless observe a rather constant temporal relation between meaning and imagery.

The introspective results and the reaction times are supplementary. When taken together they leave no doubt that we have really been investigating the temporal relation of meaning and imagery. 
VII. The Context Theory of Meaning and the Temporal Relations of MEANINg and IMAgery

It may now be asked: Whom does all this concern? Who maintains that imagery is meaning? In spite of a certain modification of the image theory of meaning, Professor Titchener's context theory cannot account for the experimental facts brought out in his own and other laboratories. From an analysis of his theory it is apparent that he maintains that meaning is often identical with imagery. In fact under the conditions of our experiments the images and words that followed upon the sensations of the stimulus words and pictures were actually the context. Analogous conscious states have been reported by Cornell observers as the meaning under somewhat similar conditions. But they did not take into consideration the temporal relations of meaning and imagery.

A brief analysis of the context theory of meaning will show how intimately it is concerned with the temporal relations of meaning and imagery.

\section{(a) Outline of the Theory}

"Meaning, psychologically, is always context." the definition that Professor Titchener gives to a fact of consciousness with which the modern psychology of thought is now interested.

What is context? Context in English is a word used to signify the setting of a sentence or a quotation-its relation to what the author has written before and after the passage in question. Titchener lays particular stress upon what comes after in the definition of psychological context. "Context, in this sense, is simply the mental process which accrues to the given process through the situation in which the organism finds itself." A sensation by itself has no meaning-neither has an image. When a second mental process accrues to a former one-this second mental process is the meaning of the first one. It does not produce a new something called mean-

1 'A Text Book of Psychology,' New York, 1911, p. 367. 
ing, it is the meaning. "One mental process is the meaning of another mental process if it is in that other's context."2

What are the mental processes that accrue to others and thus constitute their meaning? Originally the secondary process which constituted the meaning was a group of sensations coming from a bodily attitude of the organism. If the animal took an attitude of defence the kinæsthetic sensations thus aroused did not exactly mean-did not signify that something to be feared was at hand. The whole complex of sensations involved constituted the meaning "something to be feared."

At the present day, however, the human mind has passed beyond the elementary stage of the primitive organism. The essential difference between present human intelligence and its early prototype consists in the use of imagery as well as sensations for the constituents of meaning. "Image has now intervened upon sensation and meaning can be carried in imaginal terms." 2 Thus spoken and written language has become possible. A sensation arouses an image and the image-the psychological process accruing to the sensationsis the meaning of the sensation.

Various types of mind exist. Each has a special tendency to form some kind of imagery in understanding sensations. Indeed "If we were to make serious work of a differential psychology of meaning, we should probably find that in the multitudinous variety of situations and contexts, any mental process may possibly be the meaning of any other." 3

It is Professor Titchener's opinion however that of all the possible types of supplementary mental processes, two are of special importance: kinæsthesis and verbal images. Indeed he pushes the verbal theory so far as to say: "The words that we read are both perception and context of perception, the auditory kinæsthetic idea is the meaning of the visual symbols."

I p. cit., p. 367.

30 . cit., p. 367 .

3 'Lectures on the Experimental Psychology of the Thought Processes,' 1909, p. I78.

- 'A Tert-Book of Psychology,' p. 368. 
Thus far, Professor Titchener's theory is entirely psychological. But in order to meet all possible contingencies arising from introspections that he or others may report, where meaning shows no trace of a sensory conscious element -a physiological factor is introduced.

Meaning is not always conscious; $i$. e., the imaginal supplement to the sensation is not always to be found even by the most careful introspection. In such cases the sensory supplement exists- it is a physiological process in the nervous system.

Professor Titchener thus summarizes his theory of perception:

"Our account of the psychology of perception is now, in the author's view, complete. It has embraced four principal points:

"First, under the general laws of attention and the special laws of sensory connection, sensations are welded together, consolidated, incorporated into a group.

"Secondly, this group of sensations is supplemented by images.

"Thirdly, the supplemental group has a fringe, a background, a context; and this context is the psychological equivalent of its logical meaning.

"Fourthly, meaning may lapse from consciousness and conscious context may be replaced by a non-conscious nervous set." 1

The type of meaning in the third caption is decidedly different from that given a few pages previous. There meaning is context-context is the mental process that follows upon and accrues to another mental process. The examples given are the images spoken of in the second caption. Here we suddenly find that meaning does not lie in the advening images-but in their fringes.

To harmonize this new idea with what has gone before we may suppose that if meaning is conscious (in the sense of being conscious described by Titchener) it is given by the context which may be (a) a second group of sensations, (b)

1 'A Text Book of Psychology,' 191 I, p. 371. 
an image or a group of images, (c) the fringe or background of such images-the fringe itself being always understood as some kind of sensory element or elements, $(d)$ various combinations of $(a),(b)$ and $(c)$.

\section{(b) The Evidence for the Theory}

In the interests of simplicity we may leave aside the speculations about meaning in the primitive organism and confine ourselves to the explanation of the fact of meaning as we experience it.

On what then, may we ask, is the statement based that meaning is context-that it is a 'sensory complex $B$, following upon sensation or image $A$.' The points of evidence are:

1. Introspection shows that when a word or a sentence is understood and careful search is made we always find some kind of imagery-verbal, kinæsthetic, visual, etc.

Granted that this is so what does it prove? Nothing more than this. In the complex of mental processes called up by the task of understanding a word or sentence imagery is present. It does not show that this imagery is the meaning -which is the very point in question.

Titchener says: "The meaning of the printed page may now consist in the auditory-kinæsthetic accompaniment of internal speech; the word is the word's own meaning."

$\mathrm{He}$ then refers in a note to introspections in the studies of Watt and of Messer which speaks of meaning being simultaneous with auditory-kinæsthetic imagery. But such a citation is not to the point. The fact that one thing accompanies another is certainly no evidence that the two are identical.

2. Analysis shows no evidence of 'imageless thoughts.'

What analysis shows is the fact of meaning. Many observers have maintained that in their consciousness of meaning sensational elements are lacking. Professor Titchener in his analysis finds also the fact of meaning and giving to the students in his laboratory the task of reporting every mental process that they can observe, he obtains experiences

1 'Lectures on the Experimental Psychology of the Thought Process,' p. 177. 
far richer in sensational elements than are elsewhere found. Given the task, 'find imagery,' and it will certainly come. And if the subject be told to look for imageless imagery, it will not be found. Meaning and imagery however, have been found both by Professor Titchener and a number of other observers. Facts are common property. It remains for Professor Titchener to prove that meaning is identical with the concomitant or subsequent imagery. This he has not done.

The context theory of imagery demands imagery, when meaning is present. If meaning equals imagery, imagery equals imagery. No imagery-no meaning, must be the conclusion to be drawn from this theory. Nevertheless Professor Titchener shrinks from admitting all that is involved in his doctrine. Why? Because he himself has observed that there are times when he experiences meaning and is not conscious of imagery. He himself, therefore, in spite of the ease with which he images things and situations, has experienced the very state of mind the existence of which he denies.

"In rapid reading, the skimming of pages in quick succession; in the rendering of a musical composition, without hesitation or reflection, in a particular key; in shifting from one language to another as you turn to your right or lefthand neighbor at a dinner table: in these and similar cases, meaning has time and time again, no discoverable representation in consciousness." 1 No discoverable representation in consciousness means no sensational element-no sensational or imaginal complex.

What is Professor Titchener's explanation of such "imageless thoughts" that come to him as he skims over the pages of a book? He has found "imageless thoughts," what then is to be done with them? Explain them away and then deny their existence. How explain them away? Refer them to the nervous system? Meaning here is not imagery for no imagery is present. What is it then? A physiological process, without any conscious accompaniment. Why without any conscious accompaniment? Because by hypothesis the

1 'A Text-Book of Psychology,' p. 369. 
only conscious processes that come into consideration are sensations and these are lacking.

On the one hand, we have an hypothesis; on the other, a fact-the imageless consciousness of meaning (imageless thoughts) in rapid reading. The fact cannot be accounted for by the hypothesis; therefore Professor Titchener denies the fact. My consciousness of meaning is unconscious. I do not think but my nervous system is thinking for me.

The reference of imageless thought to an unconscious physiological process in the nervous system brings us to a third point in the evidence for Professor Titchener's theory.

(3) "Our psychology is to be explanatory and our explanations are to be physiological."

Adherence to this principle and the ruling out of facts that it cannot explain, give to Professor Titchener's theory a certain plausibility.

What can be referred to the nervous system is explained What cannot be referred to the nervous system is not explained. It is in fact inexplicable. There must be a mistake in the observation. It must be explained away. The nervous system with its sense organs and its centres, can apparently take care of sensations and images. It gives us the sensational elements of our conscious life and apparently excludes anything like imageless thinking. If then we are to explain 'imageless thought' we must analyze it in terms of the elements given by the nervous system, or else explain it away altogether.

Such a procedure, however, places empirical psychology not only under the dominion of metaphysics, but subjects it to one particular metaphysical theory. Under such conditions an impartial empirical study of the mind becomes impossible. Let us first study the facts of consciousness and then build up our metaphysical theories.

Professor Titchener is right in demanding that the science of psychology should be explanatory; he is wrong in maintaining that everything must be explained in consonance with a particular metaphysical theory.

I 'A Tert-Book of Psychology,' p. 370. 
As a matter of fact neither Professor Titchener nor anyone else knows the limitations nor the possibilities of the nervous system. Nor does anyone know, for that matter, what the nervous system may be called upon to do if it is to explain the facts of our conscious life. We do not know all about the facts of consciousness and until we do, explanatory psychology must be careful. We do not know all about the nervous system and it is not wise to distort the fact of consciousness to fit the narrow outlines of our present horizon.

Let us first investigate the facts of consciousness without any timidity about their ultimate explanation. Let us first find out what we have to explain, and then explain it.

The context theory of meaning is not based entirely upon such general considerations as we have picked out from Professor Titchener's writings. There are a number of experimental studies that have been put forward as tests in confirmation of the theory.

Of these, we may analyze two, leaving a more complete account of the literature to a full report of our experiments which we hope to publish later.

Helen Clarke, ${ }^{1}$ in an article on 'Conscious Attitudes' took up the problem of the understanding of words and sentences. She confirmed the reports of other observers that 'often the images are adequate, irrelevant or even contradictory' (p. 24I). The inadequacy she explained by saying that 'we have no criterion save the facts themselves, by which we can decide how clear or complete an image must be in order to carry a meaning' (p. 24I). The contradictory character she accounted for by pointing out that in every one of her cases there was 'sufficient connection between the logical meaning of the word, and the psychological context of the act of understanding, for the latter to carry a general meaning' (p. 242). The fact of irrelevancy, she said, was less easy to explain.

Miss Clarke therefore seems to be conscious of the fact that words have a logical meaning which cannot be identified with the imagery that they evolve. She distinguishes be-

1 Am. J. of Psychol., XXII., pp. 214-249. 
tween the word-the imagery that it evolves-and the meaning that is carried. She finds also that imagery is often irrelevant. Irrelevant to what, we may ask? To the meaning. She therefore realizes a difference between the psychological process called an image and another something of which she is also conscious and which may be termed the meaning of the word. Miss Clarke ${ }^{1}$ seems to look upon general meaning as a logical something of which no account need be taken in psychology. If, however, the task of psychology is to investigate all conscious processes, logical meaning cannot be ruled out as "outside the sphere of psychology.'2 For "logical meaning" is conscious. Its nature is therefore a psychological problem. It is that something to which the imagery is often inadequate, irrelevant and contradictory. Miss Clarke has implicitly at least recognized it as a conscious state, distinct from imagery.

Edmund Jacobson ${ }^{3}$ investigated by the Method of Introspection (1) The Perception of Letters, (2) The Meaning of Words, (3) The Understanding of Sentences. The instructions to his subjects (three observers) were as follows:

I. Give a minute account of all the mental processes you experience in their temporal order of sequence.

II. Put direct description of conscious processes outside of parentheses, and statements concerning meanings, objects, stimuli and physiological occurrences inside.

The experiments on the perception of letters showed that under the instructions given their meaning is usually accompanied by the arousal of what Jacobson termed designatory processes, viz., kinæsthetic or auditory sensations or both. Jacobson calls attention to the fact that "The main point to note is that the precise statement of meaning is by no means easy." Nor does he state anything more definite as to what the meaning of a letter is.

The experiments with the meaning of the words were made as follows: "A written word was laid before the observer for a period of one minute. He was instructed to fixate the

1 Along with Geissler, Am. J. of Psychol., XXIII., p. 194.

3 C. Geissler, l. $c$.

Am. J. of Psychol., 1911, XXII., pp. 553-577. 
word, to utter it with quick repetition and to get at its meaning. The concluding ten seconds were marked off by signals; and the observer's task was to report what occurred in consciousness during the particular interval." The observer reported two kinds of imagery: (a) That which appeared as the carrier of the meaning and $(b)$ that which appeared as irrelevant. No logical or psychological test could be found to distinguish between the relevant and irrelevant imagery.

The conclusion of Jacobson was "that the conscious meanings brought out in these experiments are not perfect and static logical meanings of definition. . . . Logically, the representation of meaning is inadequate; psychologically, it is adequate to the demands of the occasion" (pp. 568-569).

In his experiments on the meaning of sentences, Jacobson found cases in which (I) an automatic reading was followed by a perception of the meaning identified with images called forth by the experiment. (2) Cases in which the meaning did not come to the subject at all in spite of a wealth of visual, organic, kinæsthetic and tactual sensations.

Cases in which the visual and auditory images and sensations from reading were the sole processes present in consciousness -and yet the sentence had meaning. Jacobson concludes: (I) "Wherever there is meaning there are also processes," i.e., sensations and images of one kind or another. (2) "The correlated meanings and processes are two renderings from different points of view of the same experience."

The first conclusion seems established by the introspective reports, but it holds only for the conditions of these experiments where ample time is given for images to appear and the task is set to report primarily mental processes, i. e., sensations and images; and secondarily, in parentheses, to note meaning as it arises.

The second conclusion: (which is really the "crux" of the whole situation) meaning is an aspect of sensation and imagery, is simply stated and the reader is left to judge for himself on what evidence the conclusion is based. The only evidence in his paper for such an indentification is to be sought in the fact that his subjects, as a rule, were not satisfied that they 
had anything that corresponded with their idea of meaning till relevant imagery was present. This simply shows that meaning in the Cornell sense is not present till such imagery arises. From Jacobson's own data, it appears, however, that meaning in a broader sense must have been present when meaning in the Cornell sense was denied. When Dr. Geissler, instructor in psychology at Cornell, for 3 seconds, looked at the sentence, "Did you see him kill the man?," and then declared at the end "No meaning all the way through," we can only conclude that "meaning" must have been taken in a very restricted sense. When again he looked at the sentence, "The iron cube fell heavily on the floor," reads it as so many meaningless words, and then on rereading obtains the meaning, a very loud sound, the time of the whole procedure being 4.5 seconds, the conclusion is strengthened that during the experiment, he was seeking for a meaning in the sense of an imaginal representation. In this sense, and in no other, is Jacobson's conclusion warranted. An imaginal representation is some kind of imagery. The sweeping conclusion that meaning is an aspect of imagery requires the proof of another proposition, namely that all meaning consists in imaginal representation.

The data of this piece of introspective work is incompatible neither with the data nor the conclusions of the Külpean school. Indeed it has confirmed the fact that the meaning of a sentence may be present when the sole processes present in consciousness are the visual and auditory images and sensations from reading. And if it be true that on certain occasions, as in Geissler's case, these same processes were present and the meaning was really absent, one should conclude that they cannot be identical with the meaning. In like manner, a physician refuses to admit that a definite microörganism is the cause of a disease-if at times it is found when the disease does not occur, and the disease occurs when the organism is absent. Jacobson should therefore have admitted that there are times at least when meaning is not a mere aspect of sensations and images.

Professor Titchener looks upon the chief value of Jacob- 
son's work in making the distinctions between the mere statement that meaning is present and the analytic description of the psychological part of meaning. He says that "He finds no specific 'meaning process' underlying the statement of meaning."

True it is that Jacobson found no special sensory or imaginal process as the habitual carrier of meanings, but he did not prove that meaning is not itself a conscious process. In fact, his experiments seem rather to confirm the conclusion that meaning is not imagery, but something else altogether.

Had the Cornell School taken cognizance of the temporal relations of meaning and imagery, the context theory of meaning would have been profoundly modified. Imaginal terms may accrue to incoming sensations and constitute by definition their context. Do they constitute their meaning? A determination of the temporal relation that imagery bears to meaning shows that this is impossible. What comes after another cannot be said to cause, or constitute.it, or be identical with it. Meaning, therefore, is not context. What is ita mere negation? Not at all. It is a definite mental process sui generis. What are its qualitative characters? Some of these have been already indicated. A further development of the concept will be given with the fuller account of these investigations.

1 "Description os. Statement of Meaning," $A m$. J. of Psychol., I91 2, XXIII., p. I82. 